\title{
The Triangular Stress Diagram- A Graphical Representation of Crustal Stress Measurements
}

GEOLOGICAL SURVEY PROFESSIONAL PAPER 1291

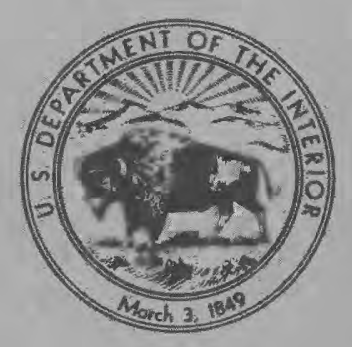





\title{
The Triangular Stress Diagram- A Graphical Representation of Crustal Stress Measurements
}

\author{
By HENRI S. SWOLFS
}

\begin{tabular}{lllll}
\hline GEOLOGICAL SURVEY & PROFESSIONAL & PAPER & 1291
\end{tabular}

A method is devised that uses a ternary

diagram to interpret point measurements of

three-dimensional stress and to assess

structural stability of crustal rocks

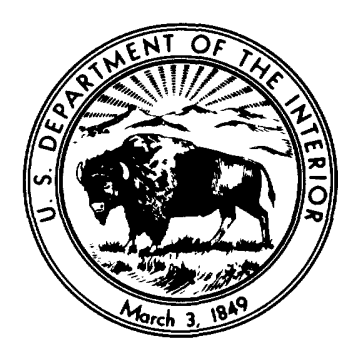




\title{
UNITED STATES DEPARTMENT OF THE INTERIOR
}

\author{
WILLIAM P. CLARK, Secretary
}

\section{GEOLOGICAL SURVEY}

\author{
Dallas L. Peck, Director
}

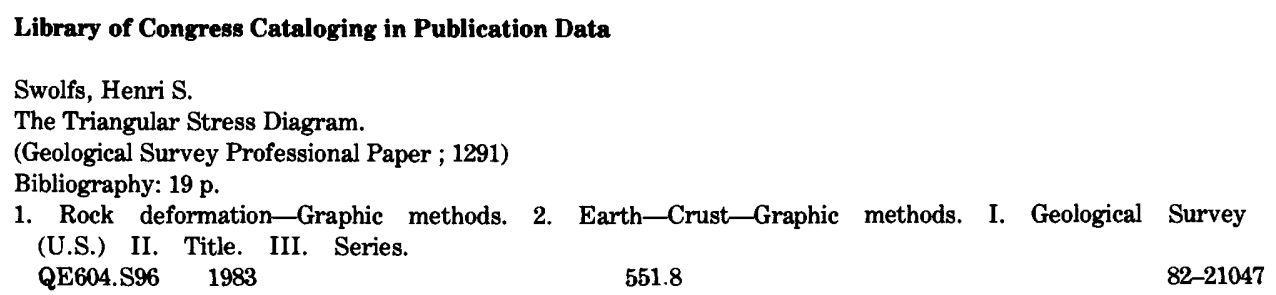

For sale by the Branch of Distribution, U.S. Geological Survey 604 South Pickett Street, Alexandria, VA 22304 


\section{CONTENTS}

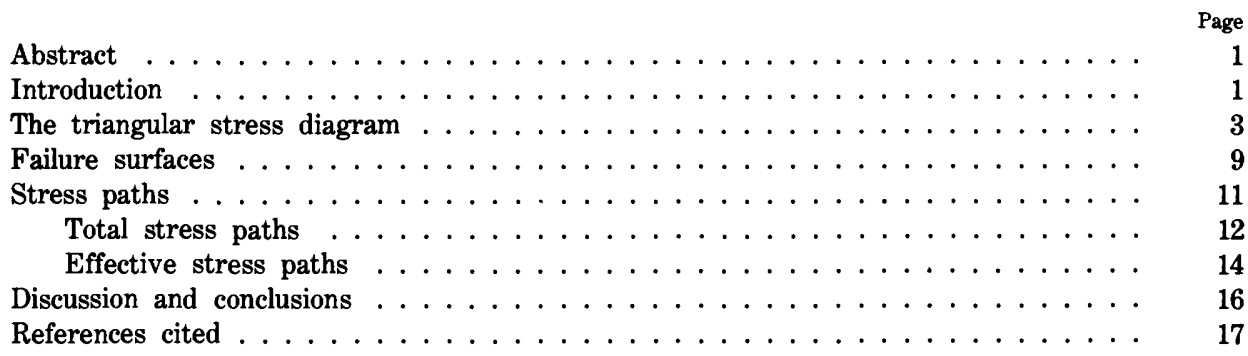

\section{ILLUSTRATIONS}

FIGURE 1. Summary plot of positive stress differences between vertical stress component and minimum horizontal stress component

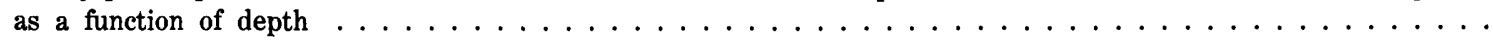

2. Summary plot of minimum horizontal to vertical stress ratios as a function of depth . . . . . . . . . . .

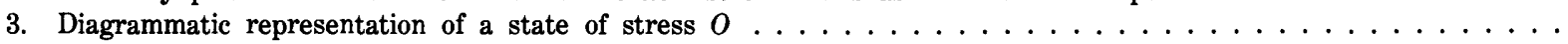

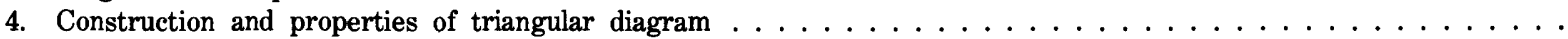

5. Triangular diagram of experimentally determined failure envelopes or surfaces . . . . . . . . . . . . .

6. Composite plot consisting of two panels of triangular diagram that combines test results for $\beta=60^{\circ} \ldots \ldots \ldots$

7. Plot of distribution of total stress states and effective stress states measured in shales and marlstones ......

8. Plot of distribution of total stress states measured in quartzitic beds of Witwatersrand Group, South Africa, and vertical

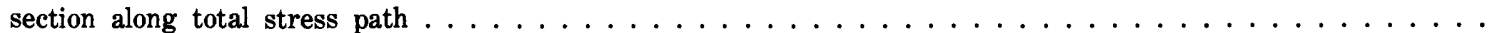

9. Plot of stress path associated with increasing hydrostatic pressure $\ldots \ldots \ldots \ldots \ldots \ldots$

10. Plot of probable relation between stress states measured at shallow depths and focal-mechanism solutions . . . . 16

\section{TABLES}

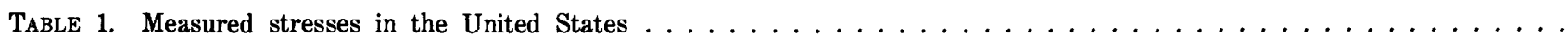

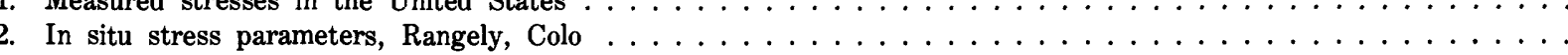




\title{
THE TRIANGULAR STRESS DIAGRAM-A GRAPHICAL REPRESENTATION OF CRUSTAL STRESS MEASUREMENTS
}

\author{
By HeNRI S. SWOLFS
}

\begin{abstract}
A new graphical method is introduced that facilitates the representation and interpretation of the generally anisotropic in situ states-ofstress measured in rocks. The purpose of the method is to clearly and easily display these stress states, each measured in terms of three values, in two-dimensional space; this is done by projecting three-dimensional stress space onto a triangular-coordinate (ternary) diagram and plotting the measured stress states as points. Failure surfaces determined either by experiment or by invoking hypothetical failure criteria are plotted on the diagram to enclose the stability field. Thus, an anisotropic stress condition measured at a given depth in the Earth's crust is represented by a single point on the triangular diagram and its relative position in the enclosed stress space may yield useful information on the degree of mechanical stability of the rock mass at the point of measurement. The method also allows the representation of any number of measured stress states in a given locality, each plotted in its own position. This method is most useful as a reconnaissance tool, provided complete measurements of in situ stress as a function of depth are available, to correlate them with information obtained by different, more indirect methods. A variety of stress paths either associated with the measured stress-depth distribution, or modified by fluid injection or mined excavations, among others, can be traced or extrapolated to establish whether the imposed disturbance leads to failure of crustal rocks.
\end{abstract}

\section{INTRODUCTION}

The development and subsequent use of field techniques to obtain stress measurements in rocks over a significant range of crustal depths has contributed important information on the in situ state of stress. Many of these results have been reported by Renalli and Chandler (1975), McGarr and Gay (1978), Brown and Hoek (1978), among others. Because an adverse change in crustal stresses may result in the eventual instability of the rock mass, knowledge of their present distribution in reasonable detail is important. From this detail can be derived the kind of information that is particularly relevant to the design and long-term maintenance of underground structures and civil engineering works, and to the understanding of earthquake mechanics.

A state of stress is completely defined by three principal stress components and their orientations, $S_{1}>S_{2}>S_{3}$ (total stresses) or $\sigma_{1}>\sigma_{2}>\sigma_{3}$ (effective stresses). Compressive stresses are reckoned positive and effective stresses are equal to the total stresses less the interstitial pore pressure $(P)$ provided the rocks are sufficiently permeable; that is, $\sigma=S-P$. Failure criteria generally are expressed in terms of effective stresses. With reference to crustal stresses, a common assumption (Anderson, 1951) is that the vertical total stress, $S_{v}$, is also a principal stress, $S_{1}, S_{2}$, or $S_{3}$. Likewise, $S_{\text {hmax }}$ and $S_{\text {hmin }}$ are the maximum and minimum horizontal total stresses and principal stresses.

Figures 1 and 2 summarize the author's compilation (Swolfs and others, 1977) of the then available stress measurements obtained from hydraulic-fracturing tests in the United States (see also McGarr and Gay, 1978). Only the data for $S_{v}$ (overburden pressure) and $S_{h \text { min }}$ (assumed equal to the measured instantaneous shut-in pressure, ISIP) are plotted against depth to provide geologic perspective. No attempt at averaging the two horizontal stress components, $S_{\text {hmax }}$ (if known) and $S_{\text {hmin }}$, has been made because otherwise useful information becomes somewhat obscure. A complete listing of the data used in figures 1 and 2 may be found in table 1.

When the field data are ranked with the type and geologic age of the rock in which the measurements were made, several observations can be made. For example, at or near the Earth's surface, the horizontal stresses tend to equal or exceed the vertical stress, whereas at greater depths the vertical stress becomes the more dominant component (figs. 1 and 2). This general phenomenon, recognized in many localities around the world, is perhaps associated with the effects of erosional unloading (denudation) of the rock exposed at the Earth's surface (Voight, 1966) and is especially pronounced in the crystalline, brittle rocks. The data also provide cogent evidence for the proposition (Griggs, 1936) that rocks possess long-term strengths; that is, in the absence of external influences, rocks are capable of sustaining finite stress differences over geologically significant times without continuously deforming. The 


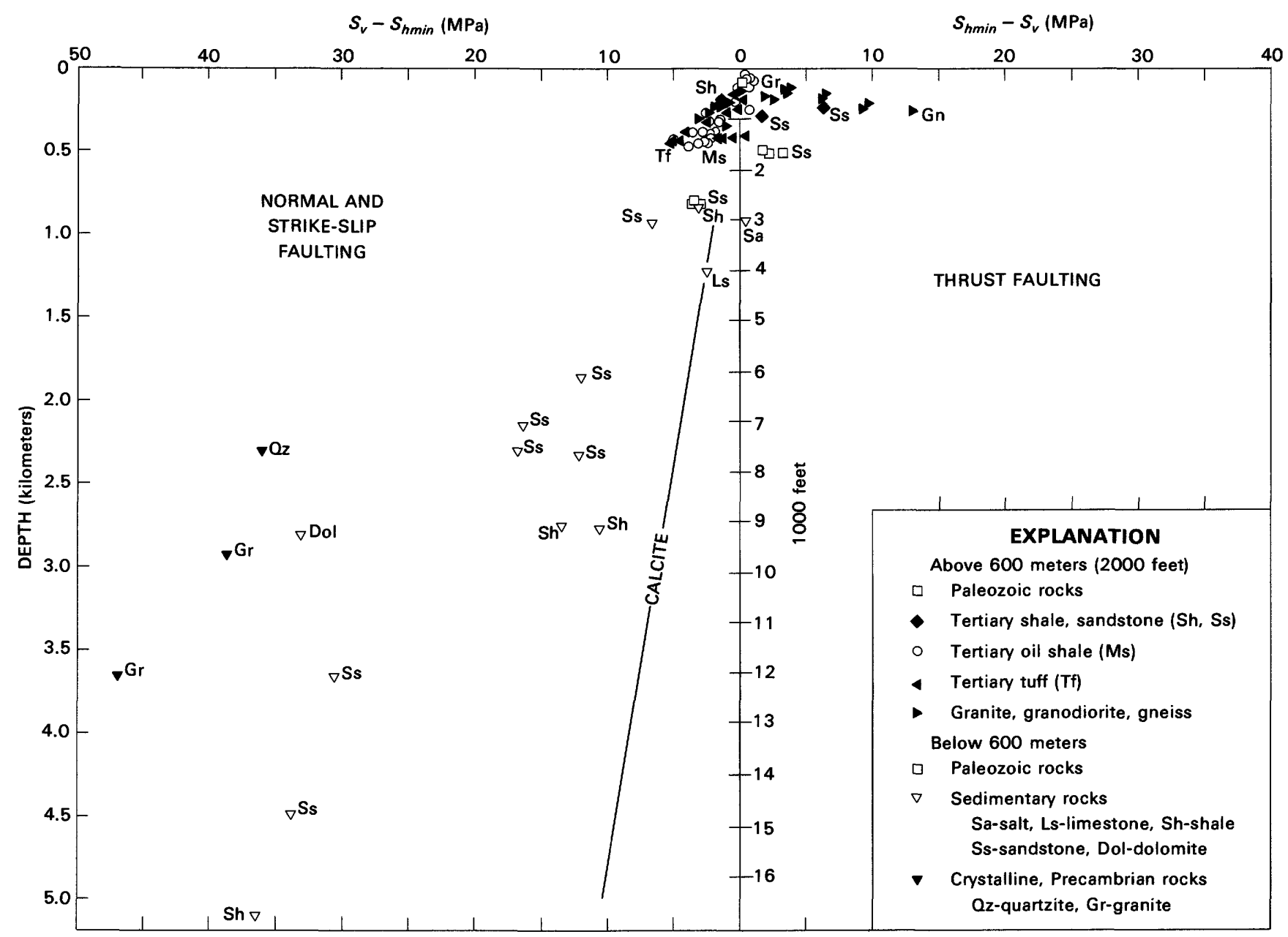

FIgURE 1.-Summary plot of the positive stress differences in megapascals $(\mathrm{MPa})$ between the vertical stress component $(=\rho g h)$ and the minimum horizontal stress component $(=I S I P)$ as a function of depth. Lithologies are identified by the abbreviations: Gr, granite; Gn, gneiss; Qz, quartzite; Dol, dolomite; Ss, sandstone; Ls, limestone; Sh, shale; Sa, salt; Tf, tuff; and Ms, marlstone. In the left panel, the magnitude of the vertical stress component is either intermediate or greatest in value; in the right panel the vertical stress magnitude is least in value. The line marked "calcite" indicates the stress differences inferred for limestones in the Gulf coastal region (Friedman and Heard, 1974).

magnitudes of the stress differences (fig. 1) or stress ratios (fig. 2) depend in large measure on rock type and increase with pressure (depth) under normal geothermal conditions. At one end of the spectrum (fig. 2), the strong "brittle" rocks, including dolomite, granite, and quartzite, maintain stresses that approach the short-term failure strength (see also Handin and others, 1963, figs. 26 and 27). At the other end of the spectrum, such "ductile" rocks as salt, limestone, and some shales persist in supporting low stresses that probably are related to their respective long-term yield or creep strengths. In support of this latter observation, Friedman and Heard (1974) found, by analyzing the growth of mechanical twins in calcite, that Lower Cretaceous limestones in the Gulf Coast area have maintained a nearly constant horizontal-to-vertical stress ratio of 0.91 over a depth range of $6.5 \mathrm{~km}$ (calcite line in figs. 1 and 2); this ratio is considered to be a maximum.

Hypothetically, therefore, the suggestion may be entertained that in a typical vertical rock sequence composed of, say, granite, shale, dolomite, limestone, and sandstone, the stresses in each rock unit are limited over the long term by the respective strengths, resulting in an inhomogeneous horizontal stress distribution throughout modified to varying degrees by the processes of burial, denudation, and tectonics. At the same time, the vertical stresses and, for reasons of equilibrium and continuity, the shear stresses, must be smooth varying functions of depth. The evidence, clearly, is mixed for the very reason that the already limited data base also is incomplete (figs. 1 and 2). The resolution of the ambiguities would require the analyses of com- 


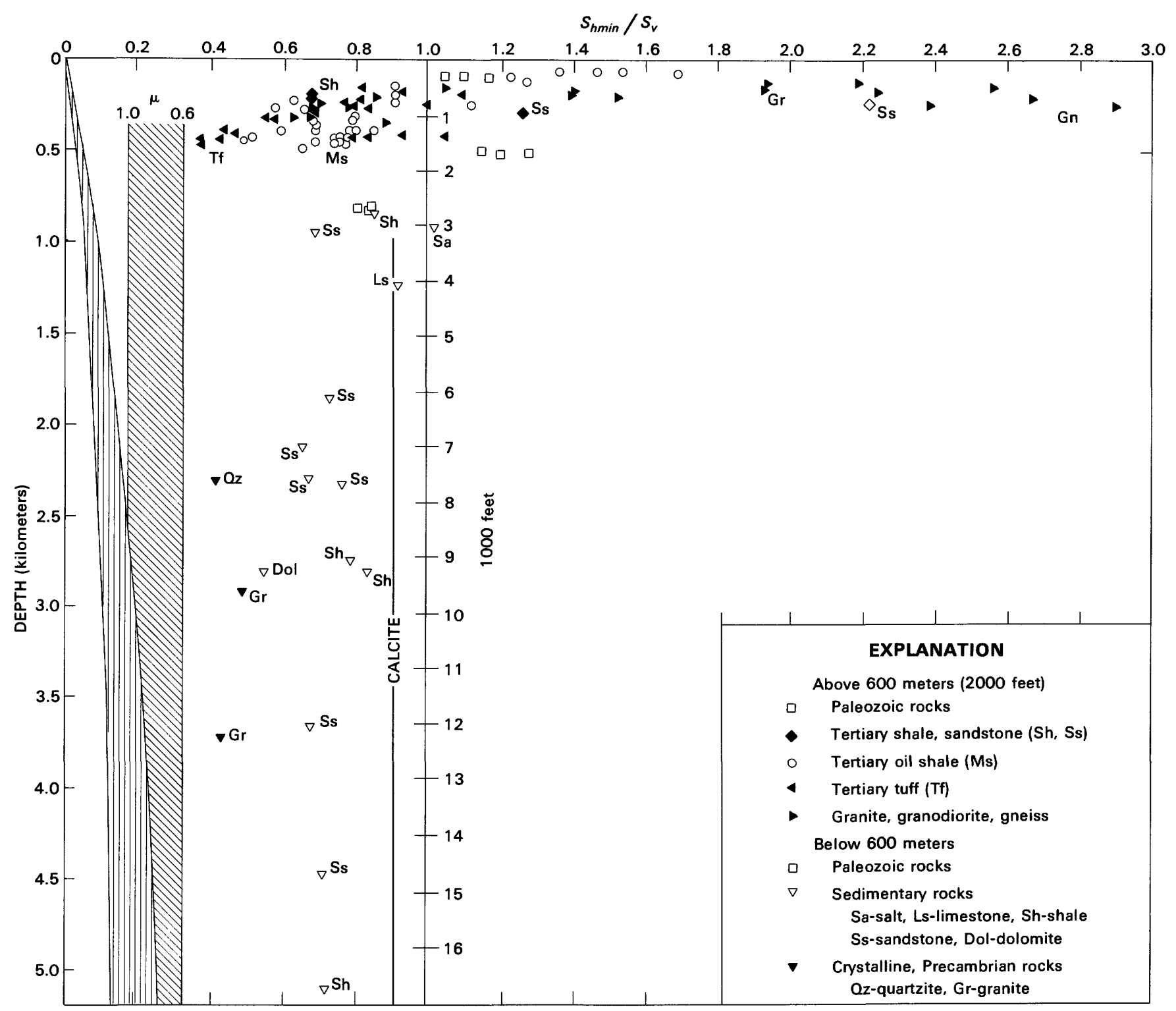

Figure 2.-Summary plot of the minimum horizontal to vertical stress ratios as a function of depth. Lithologies are identified by the abbreviations: Gr, granite; Gn, gneiss; Qz, quartzite; Dol, dolomite; Ss, sandstone; Ls, limestone; Sh, shale; Sa, salt; Tf, tuff; and Ms, marlstone. The shaded curved band in the far left panel represents the short-term rupture strengths of intact crystalline rocks tested to failure under conventional triaxial stress conditions and strain rates. The frictional strengths of preexisting faults and fractures are bounded by two values for the coefficient of sliding friction ( $\mu=0.6$ and 1.0).

plete states of stress (three-dimensional) and their distribution in the rock column.

The purpose of this paper is to introduce an alternative to the three-dimensional space coordinate plot (Meldahl, 1944) in which the states of stress are uniquely represented as points. The present method involves the transformation of rectangular-coordinate stress space into a triangular-coordinate system and plotting the measured states of stress in the Earth's crust in dimensionless units in a triangular (ternary) diagram familiar to geologists.

\section{THE TRIANGULAR STRESS DIAGRAM}

A particular compressive state of stress, $O$, defined by three principal stresses and their orientations, can be represented in a rectangular system of coordinates as a point in principal stress space (fig. 3). Let the coordinates of the Cartesian set of axes be defined by the principal stress components $S_{x}^{c}, S_{y}^{c}$, and $S_{z}^{c}$. The position of stress state $O$ relative to the space diagonal $H$ can be represented by the resultant vector $r$ (fig. 
TABLE 1.-Measured stresses in the United States

[MPa, megapascals; leaders (--) indicate no data]

\begin{tabular}{|c|c|c|c|c|c|c|c|c|c|}
\hline State & Lithology & Age & $\begin{array}{l}\text { Depth } \\
\text { (meters) }\end{array}$ & $\begin{array}{c}\mathrm{S}_{\mathrm{v}} \\
(\mathrm{MPa})\end{array}$ & $\begin{array}{l}S_{h_{\min }} \\
(\mathrm{MPa})\end{array}$ & $S_{n m i n} / S_{v}$ & $\begin{array}{l}S_{h \max } \\
(\mathrm{MPa})\end{array}$ & $\begin{array}{l}\text { Fracture } \\
\text { direction }\end{array}$ & References $^{1}$ \\
\hline \multirow[t]{2}{*}{ California-- } & Sandstone-- & Tertiary & $\begin{array}{l}240 \\
287\end{array}$ & $\begin{array}{l}5.1 \\
6.5\end{array}$ & $\begin{array}{r}11.4 \\
8.2\end{array}$ & $\begin{array}{l}2.22 \\
1.26\end{array}$ & $\begin{array}{r}22.5 \\
\cdots .\end{array}$ & N. $15^{\circ} \mathrm{E}$. & $\begin{array}{l}27 . \\
\text { Do. }\end{array}$ \\
\hline & Granite-...- & Jurassic-...... & $\begin{array}{l}157 \\
210 \\
234 \\
240 \\
265 \\
292 \\
308\end{array}$ & $\begin{array}{l}4.2 \\
5.7 \\
6.3 \\
6.5 \\
7.2 \\
7.9 \\
8.3\end{array}$ & $\begin{array}{l}4.4 \\
4.9 \\
4.4 \\
5.1 \\
4.9 \\
5.4 \\
5.2\end{array}$ & $\begin{array}{l}1.05 \\
.86 \\
.70 \\
.78 \\
.68 \\
.69 \\
.63\end{array}$ & $\begin{array}{r}5.2 \\
7.0 \\
7.4 \\
7.5 \\
8.0 \\
10.9 \\
10.0\end{array}$ & $\begin{array}{c}\cdots \\
\cdots \\
\cdots \\
\cdots \\
\cdots \\
\cdots \\
\text { N. } \\
25^{\circ} \text { E. }\end{array}$ & $\begin{array}{l}10,11,14 . \\
\text { Do. } \\
\text { Do. } \\
\text { Do. } \\
\text { Do. } \\
\text { Do. } \\
\text { Do. }\end{array}$ \\
\hline \multirow[t]{10}{*}{ Colorado--- } & $\begin{array}{l}\text { Marlstone- } \\
\text { shale. }\end{array}$ & Tertiary ....... & $\begin{array}{r}37 \\
158 \\
190 \\
267 \\
338 \\
385 \\
406 \\
442 \\
451\end{array}$ & $\begin{array}{r}.9 \\
3.6 \\
4.3 \\
6.0 \\
7.6 \\
8.7 \\
9.2 \\
10.2 \\
10.2\end{array}$ & $\begin{array}{l}1.3 \\
3.3 \\
3.9 \\
3.5 \\
5.3 \\
6.0 \\
7.0 \\
7.4 \\
7.5\end{array}$ & $\begin{array}{l}1.44 \\
.92 \\
.91 \\
.58 \\
.70 \\
.69 \\
.76 \\
.74 \\
.74\end{array}$ & $\begin{array}{l}1.3 \\
4.8 \\
4.8 \\
4.0 \\
6.8 \\
8.3 \\
9.1 \\
8.0 \\
9.5\end{array}$ & 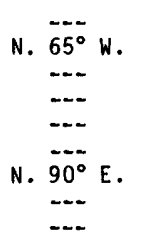 & $\begin{array}{l}4,25 . \\
\text { Do. } \\
\text { Do. } \\
\text { Do. } \\
\text { Do. } \\
\text { Do. } \\
\text { Do. } \\
\text { Do. } \\
\text { Do. }\end{array}$ \\
\hline & & & $\begin{array}{r}64 \\
92 \\
110\end{array}$ & $\begin{array}{l}1.4 \\
2.1 \\
2.5\end{array}$ & $\begin{array}{l}2.2 \\
2.5 \\
2.3\end{array}$ & $\begin{array}{r}1.57 \\
1.19 \\
.92\end{array}$ & $\begin{array}{l}4.0 \\
--. \\
3.6\end{array}$ & $\ddot{E-W}$ & $\begin{array}{l}\text { Do. } \\
\text { Do. } \\
\text { Do. }\end{array}$ \\
\hline & & & $\begin{array}{r}61 \\
425 \\
443 \\
449\end{array}$ & $\begin{array}{r}1.4 \\
9.6 \\
10.0 \\
10.1\end{array}$ & $\begin{array}{l}1.9 \\
7.5 \\
7.5 \\
7.8\end{array}$ & $\begin{array}{r}1.36 \\
.78 \\
.75 \\
.77\end{array}$ & $\begin{array}{l}1 . .8 \\
11.8 \\
11.3 \\
11.3\end{array}$ & $\begin{array}{l}\cdots-- \\
E-W \\
E-W\end{array}$ & $\begin{array}{l}\text { Do. } \\
\text { Do. } \\
\text { Do. } \\
\text { Do. }\end{array}$ \\
\hline & & & $\begin{array}{l}269 \\
319 \\
384 \\
423 \\
430\end{array}$ & $\begin{array}{l}6.1 \\
7.2 \\
8.7 \\
9.6 \\
9.7\end{array}$ & $\begin{array}{l}4.1 \\
4.9 \\
5.2 \\
5.0 \\
4.7\end{array}$ & $\begin{array}{l}.67 \\
.68 \\
.60 \\
.52 \\
.48\end{array}$ & $\begin{array}{l}\ldots \\
\ldots \\
6.6 \\
5.6\end{array}$ & $\ldots$ & $\begin{array}{l}\text { Do. } \\
\text { Do. } \\
\text { Do. } \\
\text { Do. } \\
\text { Do. }\end{array}$ \\
\hline & & & $\begin{array}{l}313 \\
378 \\
402 \\
453 \\
476\end{array}$ & $\begin{array}{r}7.1 \\
8.6 \\
9.1 \\
10.2 \\
10.8\end{array}$ & $\begin{array}{l}5.7 \\
6.8 \\
7.1 \\
7.1 \\
7.0\end{array}$ & $\begin{array}{l}.80 \\
.79 \\
.78 \\
.70 \\
.65\end{array}$ & $\begin{array}{r}8.6 \\
10.6 \\
9.5 \\
9.5 \\
8.3\end{array}$ & N. $\overline{87^{\circ}}$ E. & $\begin{array}{l}\text { Do. } \\
\text { Do. } \\
\text { Do. } \\
\text { Do. } \\
\text { Do. }\end{array}$ \\
\hline & & & $\begin{array}{r}72 \\
108 \\
237 \\
248 \\
320 \\
385\end{array}$ & $\begin{array}{l}1.6 \\
2.4 \\
5.4 \\
5.6 \\
7.2 \\
8.7\end{array}$ & $\begin{array}{l}2.7 \\
3.1 \\
4.3 \\
6.3 \\
5.7 \\
7.4\end{array}$ & $\begin{array}{r}1.69 \\
1.29 \\
.80 \\
1.13 \\
.79 \\
.85\end{array}$ & $\begin{array}{r}5.0 \\
5.6 \\
5.8 \\
\ldots- \\
\ldots-. \\
13.0\end{array}$ & $\begin{array}{l}\cdots \\
\cdots \\
\text { N. } 75^{\circ} \\
\text { N. } 45^{\circ} \text { W. } \\
\text { N. } 75^{\circ} \text { W. }\end{array}$ & $\begin{array}{l}\text { Do. } \\
\text { Do. } \\
\text { Do. } \\
\text { Do. } \\
\text { Do. } \\
\text { Do. }\end{array}$ \\
\hline & & & 216 & 4.9 & 2.6 & .53 & 3.1 & -.. & Do. \\
\hline & Sands tone-- & $\begin{array}{l}\text { Pennsyl vani an- } \\
\text { Permian. }\end{array}$ & 1914 & 42.7 & 31.4 & .74 & 55.2 & N. $70^{\circ} \mathrm{E}$. & $7,10,19,20$. \\
\hline & Sands tone-- & Cretaceous-... & $\begin{array}{l}2303 \\
2322\end{array}$ & $\begin{array}{l}52.1 \\
52.5\end{array}$ & $\begin{array}{l}34.4 \\
40.4\end{array}$ & $\begin{array}{l}.68 \\
.77\end{array}$ & $\ldots$ & $\begin{array}{l}\text { N. } 20^{\circ} \mathrm{W} . \\
\text { N. } 15^{\circ} \mathrm{W} .\end{array}$ & $\begin{array}{l}23 . \\
\text { Do. }\end{array}$ \\
\hline & Granite-..- & Precambrian--- & 3660 & 82.8 & 35.9 & .43 & $\ldots$ & N. $60^{\circ}$ W. & 20. \\
\hline Idaho-.......... & Quartzite-- & Precambrian--- & 2300 & 62.0 & 26.0 & .42 & 42.8 & N. $75^{\circ} \mathrm{W}$. & 13. \\
\hline 111 inois & Limestone-- & Pennsyl vani an- & $\begin{array}{r}94 \\
97 \\
97 \\
100\end{array}$ & $\begin{array}{l}2.1 \\
2.2 \\
2.2 \\
2.3\end{array}$ & $\begin{array}{l}2.3 \\
2.3 \\
2.3 \\
2.7\end{array}$ & $\begin{array}{l}1.10 \\
1.05 \\
1.05 \\
1.17\end{array}$ & $\ldots$ & $\begin{array}{l}\text { N. } 66^{\circ} \mathrm{E} . \\
\text { N. } 58^{\circ} \mathrm{E} \text {. } \\
\text { N. } 72^{\circ} \mathrm{E} . \\
\text { N. } 62^{\circ} \mathrm{E} .\end{array}$ & $\begin{array}{l}5,6,10 . \\
\text { Do. } \\
\text { Do. } \\
\text { Do. }\end{array}$ \\
\hline \multirow[t]{4}{*}{ Michigan--.- } & Limestane-- & Devonian -...... & 1230 & 32.0 & 29.5 & .92 & 50.5 & $\ldots$ & $10,11,15$ \\
\hline & Dolomite-.. & Ordovician-... & 2806 & 73.0 & 40.0 & .55 & 56.0 & $\ldots$ & Do. \\
\hline & Sandstone-- & Cambrian-.....- & 3660 & 95.0 & 64.5 & .68 & 88.5 & $\ldots$ & Do. \\
\hline & Shal e........ & Precambrian-..- & 5105 & 132.5 & 96.0 & .72 & 147.0 & $\ldots$ & Do. \\
\hline
\end{tabular}

1 References:

1. Aamodt (1977).

2. Blair and others (1977).

3. Brechtel and others (1976).

4. Bredehoef $t$ and others (1976).

5. Haimson and Stahl (1969).

6. Haimson and Fairhurst (1970).

7. Haims on (1973).

8. Haimson (1974).

9. Haimson and others (1974).

10. Haimson (1977a).

11. Haimson (1976).

12. Haimson and others (1976).

13. B. C. Haims on (written commun., 1976).

14. Haimson (1977b).

15. Haimson $(1977 \mathrm{C})$. 
TABLE 1.-Measured stresses in the United States-Continued

\begin{tabular}{|c|c|c|c|c|c|c|c|c|c|}
\hline State & Lithology & Age & $\begin{array}{l}\text { Depth } \\
\text { (meters) }\end{array}$ & $\begin{array}{c}\mathrm{S}_{\mathrm{v}} \\
(\mathrm{MPa})\end{array}$ & $\begin{array}{l}S_{\text {hmin }} \\
(\mathrm{MPa})\end{array}$ & $s_{n \min } / s_{v}$ & $\begin{array}{l}S_{h \max } \\
(\mathrm{MPa})\end{array}$ & $\begin{array}{l}\text { Fracture } \\
\text { direction }\end{array}$ & References ${ }^{1}$ \\
\hline \multirow[t]{3}{*}{ Nevada-......- } & Tuff---.--- & Tertiary------ & $\begin{array}{l}380 \\
268 \\
263 \\
400 \\
153 \\
165 \\
183\end{array}$ & $\begin{array}{l}7.0 \\
4.9 \\
4.8 \\
7.3 \\
2.8 \\
3.0 \\
3.3\end{array}$ & $\begin{array}{l}3.1 \\
4.1 \\
3.3 \\
3.4 \\
2.3 \\
2.8 \\
3.6\end{array}$ & $\begin{array}{r}.44 \\
.84 \\
.69 \\
.47 \\
.82 \\
.93 \\
1.09\end{array}$ & $\begin{array}{r}--- \\
10.7 \\
9.2 \\
9.1 \\
7.3 \\
8.0 \\
6.8\end{array}$ & N. $\begin{array}{l}--- \\
35^{\circ} \\
--- \\
--- \\
--- \\
--\end{array}$ & $\begin{array}{l}9,24 . \\
\text { Do. } \\
\text { Do. } \\
\text { Do. } \\
\text { Do. } \\
\text { Do. } \\
\text { Do. }\end{array}$ \\
\hline & & & $\begin{array}{l}214 \\
235 \\
249 \\
326 \\
309 \\
437\end{array}$ & $\begin{array}{l}3.9 \\
4.3 \\
4.1 \\
5.9 \\
5.6 \\
7.9\end{array}$ & $\begin{array}{l}3.2 \\
3.3 \\
4.1 \\
3.4 \\
3.1 \\
3.4\end{array}$ & $\begin{array}{r}.82 \\
.77 \\
1.00 \\
.58 \\
.55 \\
.43\end{array}$ & $\begin{array}{l}6.9 \\
--- \\
--- \\
--- \\
---\end{array}$ & N. $\begin{array}{l}--- \\
-\overline{--} \\
--- \\
---\end{array}$ & $\begin{array}{l}\text { Do. } \\
\text { Do. } \\
\text { Do. } \\
\text { Do. } \\
\text { Do. } \\
\text { Do. }\end{array}$ \\
\hline & & & $\begin{array}{l}437 \\
454 \\
420 \\
420 \\
420 \\
408 \\
416\end{array}$ & $\begin{array}{l}7.9 \\
8.2 \\
7.6 \\
7.6 \\
7.6 \\
7.3 \\
7.5\end{array}$ & $\begin{array}{l}3.0 \\
3.1 \\
6.0 \\
6.4 \\
6.0 \\
7.7 \\
7.0\end{array}$ & $\begin{array}{r}.38 \\
.38 \\
.79 \\
.84 \\
.79 \\
1.05 \\
.93\end{array}$ & $\begin{array}{r}\overline{7 .-} \\
-. \\
-.5 \\
12.5 \\
13.1 \\
12.3\end{array}$ & 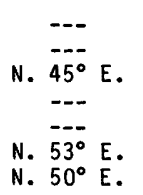 & $\begin{array}{l}\text { Do. } \\
\text { Do. } \\
\text { Do. } \\
\text { Do. } \\
\text { Do. } \\
\text { Do. } \\
\text { Do. }\end{array}$ \\
\hline \multirow[t]{2}{*}{ New Mexico-- } & Sands tone-- & Cretaceous---- & $\begin{array}{r}934 \\
2150\end{array}$ & $\begin{array}{l}21.1 \\
48.6\end{array}$ & $\begin{array}{l}14.5 \\
32.3\end{array}$ & $\begin{array}{l}.69 \\
.66\end{array}$ & --- & N. $\overline{55^{\circ}} \mathrm{E}$. & $\begin{array}{l}18 . \\
\text { Do. }\end{array}$ \\
\hline & Granite---- & Precambrian--- & $\begin{array}{r}765 \\
1990 \\
2930\end{array}$ & $\begin{array}{l}18.0 \\
50.4 \\
75.3\end{array}$ & $\begin{array}{l}14.7 \\
33.3 \\
36.7\end{array}$ & $\begin{array}{l}.82 \\
.66 \\
.49\end{array}$ & --- & N. $35^{\circ} \mathrm{E}$ & $\begin{array}{l}1,2 . \\
\text { Do. } \\
\text { Do. }\end{array}$ \\
\hline New York---- & Sandstone-- & Devonian------ & $\begin{array}{l}491 \\
512 \\
510\end{array}$ & $\begin{array}{l}11.1 \\
11.6 \\
11.6\end{array}$ & $\begin{array}{l}12.8 \\
13.9 \\
14.9\end{array}$ & $\begin{array}{l}1.15 \\
1.20 \\
1.28\end{array}$ & --- & $\begin{array}{l}\text { N. } 87^{\circ} \mathrm{E} . \\
\text { N. } 65^{\circ} \mathrm{E} . \\
\text { N. } 74^{\circ} \mathrm{E} \text {. }\end{array}$ & $\begin{array}{l}\text { 5,8. } \\
\text { Do. } \\
\text { Do. }\end{array}$ \\
\hline Onio-------- & Sands tone-- & Silurian---.--- & $\begin{array}{l}800 \\
812 \\
815\end{array}$ & $\begin{array}{l}18.8 \\
18.4 \\
18.5\end{array}$ & $\begin{array}{l}15.4 \\
14.9 \\
15.6\end{array}$ & $\begin{array}{l}.85 \\
.81 \\
.84\end{array}$ & $--\cdot$ & $\begin{array}{l}\text { N. } 62^{\circ} \mathrm{E} . \\
\text { N. } 68^{\circ} \mathrm{E} \text {. } \\
\text { N. } 67^{\circ} \mathrm{E} \text {. }\end{array}$ & $\begin{array}{l}5,6,8,10 . \\
\text { Do. } \\
\text { Do. }\end{array}$ \\
\hline \multirow[t]{2}{*}{ S.c.-...-...- } & Shale------- & Tertiary------ & $\begin{array}{l}194 \\
210\end{array}$ & $\begin{array}{l}4.4 \\
4.7\end{array}$ & $\begin{array}{l}3.0 \\
3.2\end{array}$ & $\begin{array}{l}.68 \\
.68\end{array}$ & 4.8 & N. $51^{\circ} \mathrm{E}$ & $\begin{array}{l}26 . \\
\text { Do. }\end{array}$ \\
\hline & Gneiss----- & Precambrian--- & $\begin{array}{l}120 \\
150 \\
180 \\
215 \\
245 \\
250\end{array}$ & $\begin{array}{l}3.2 \\
4.1 \\
4.9 \\
5.8 \\
6.6 \\
6.9\end{array}$ & $\begin{array}{r}7.0 \\
10.5 \\
11.0 \\
15.5 \\
15.8 \\
20.0\end{array}$ & $\begin{array}{l}2.19 \\
2.56 \\
2.24 \\
2.67 \\
2.39 \\
2.90\end{array}$ & $\begin{array}{r}8.9 \\
15.0 \\
14.0 \\
27.3 \\
17.5 \\
--.\end{array}$ & N. $\begin{array}{l}--- \\
-\cdots \\
-\cdots \\
-\cdots\end{array}$ & $\begin{array}{l}10,11,14 . \\
\text { Do. } \\
\text { Do. } \\
\text { Do. } \\
\text { Do. } \\
\text { Do. }\end{array}$ \\
\hline S. Dak..-.-- & Granite---- & Precambrian--- & 1890 & 55.2 & 18.0 & .33 & 35.9 & N. $50^{\circ} \mathrm{E}$. & 28. \\
\hline Texas-.......- & Granite---- & Precambrian--- & 346 & 8.5 & 7.6 & .89 & 28.3 & N. $67^{\circ} \mathrm{E}$. & 21. \\
\hline Utah----...-- & Shale--.---- & Cretaceous---- & 2750 & 65.0 & 51.5 & .79 & 56.9 & N. $60^{\circ}$ W. & 3. \\
\hline W. Va.----- & $\begin{array}{l}\text { Shale---.-- } \\
\text { Salt---.-- }\end{array}$ & $\begin{array}{l}\text { Devonian--.-- } \\
\text { Pennsylvanian- }\end{array}$ & $\begin{array}{l}840 \\
914\end{array}$ & $\begin{array}{l}22.1 \\
20.7\end{array}$ & $\begin{array}{l}16.3 \\
21.2\end{array}$ & $\begin{array}{r}.74 \\
1.02\end{array}$ & $\begin{array}{r}38.5 \\
-. .-\end{array}$ & N. $50^{\circ} \mathrm{E}$. & $\begin{array}{l}3,16 \\
29\end{array}$ \\
\hline Wisconsin--- & Granite---- & Precambrian--- & $\begin{array}{l}135 \\
150 \\
169 \\
174 \\
188\end{array}$ & $\begin{array}{l}3.5 \\
3.9 \\
4.4 \\
4.5 \\
4.9\end{array}$ & $\begin{array}{l}6.8 \\
7.5 \\
6.2 \\
6.3 \\
7.5\end{array}$ & $\begin{array}{l}1.94 \\
1.92 \\
1.41 \\
1.40 \\
1.53\end{array}$ & $\begin{array}{l}15.9 \\
18.5 \\
16.0 \\
17.5 \\
11.7\end{array}$ & $\begin{array}{l}--- \\
--- \\
--- \\
---\end{array}$ & $\begin{array}{l}10,11,12,17 . \\
\text { Do. } \\
\text { Do. } \\
\text { Do. } \\
\text { Do. }\end{array}$ \\
\hline \multirow[t]{2}{*}{ Wyoming----- } & Shale--..-.- & Tertiary------ & 2769 & 62.6 & 52.0 & .83 & --- & N. $25^{\circ} \mathrm{E}$. & 18. \\
\hline & Sands tone-- & Jurassic-----. & 4484 & 115.1 & 81.3 & .71 &.-- & --- & 22. \\
\hline
\end{tabular}

\footnotetext{
16. Haimson (1977d).

7. Brown and Hoek (1978).

23. Smith and others (1976).

8. Power and others (1975).

24. Tyler and Vollendorf (1975).

26. Zoback and Healy (1977).

20. Raleigh (1972). Zoback and others (1977).

21. Roegiers and Fairhurst (1973). 28. E. R. Hoskins (written commun., 1977).

22. Simonson and Jones (1976). 29. A. H. Jones (oral commun., 1977).
} 
3) normal to the space diagonal whose magnitude is given by (Meldahl, 1944)

$$
r=\frac{1}{\sqrt{3}} \sqrt{\left(S_{x}^{c}-S_{y}^{c}\right)^{2}+\left(S_{y}^{c}-S_{z}^{c}\right)^{2}+\left(S_{z}^{c}-S_{x}^{c}\right)^{2}}
$$

or, in terms of the second stress-deviation invariant, $J_{2}$, as

$$
r=\sqrt{2 J_{2}}
$$

Both $O$ and $r$ lie in a plane defined by $S_{x}^{c}+S_{y}^{c}+S_{z}^{c}=$ constant and which is perpendicular to $H$. The intersection of this plane with the compressive quadrant of principal stress space results in the triangle $A B C$ whose sides make an angle of arc cos $(\sqrt{2})^{-1}=45^{\circ}$ with all three rectangular axes. By projecting the stresses $S_{x}^{c}, S_{y}^{c}$, and $S_{z}^{c}$ onto the sides of the triangle $A B$, $C A$, and $B C$, respectively, a new set of stress coordinates are obtained such that

$$
S_{x}=\sqrt{2} S_{x}^{c}, S_{y}=\sqrt{2} S_{y}^{c} \text {, and } S_{z}=\sqrt{2} S_{z}^{c}
$$

This new projection implies that the origin of rectangular space is projected onto the apices of the triangle rather than along the space diagonal as it is in the axionometric projection of Meldahl (1944). An important result of this new projection is that stress states that vary only by added hydrostatic pressure occupy different positions in the plane of the triangle; other consequences are described later in this section. In terms of the new triangular stress coordinates, the vector $r$ is given by

$$
r=\frac{1}{\sqrt{6}} \sqrt{\left(S_{x}-S_{y}\right)^{2}+\left(S_{y}-S_{z}\right)^{2}+\left(S_{z}-S_{x}\right)^{2}}=\sqrt{J_{2}} .
$$

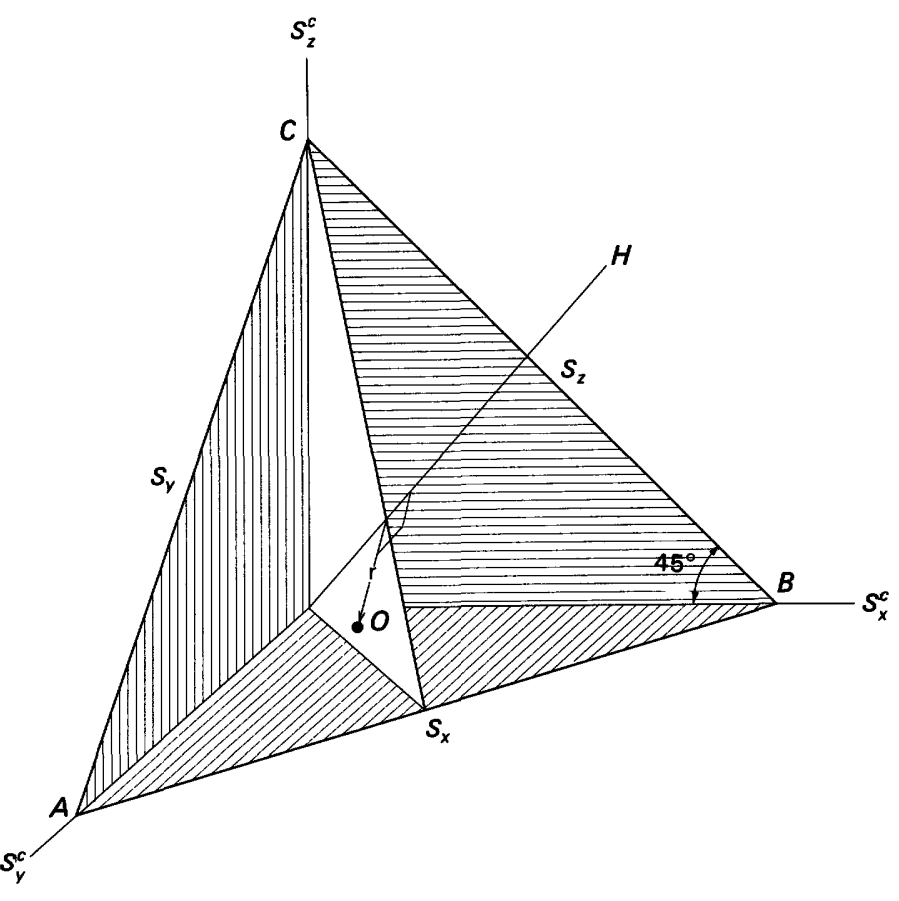

FIGURE 3.-Representation of a state of stress 0 in rectangular- coordinate space ( $S_{x}^{c}, S_{y}^{c}$, and $S_{z}^{c}$ ) and, alternatively, in triangular coordinates $\left(S_{x}, S_{y}\right.$, and $S_{z}$ ) on a plane $A B C$ through 0 perpendicular to the space diagonal $H$. The position of $O$ relative to $H$, either in the positive (compressive) quadrant of rectangular stress space or in the plane $A B C$, is given by the vector $r$, which is a measure of the stress deviation. Direction of shading indicates the direction of projection of the rectangular axes onto the sides of the triangular plane.

An added convenience is obtained by normalizing the stress components with respect to their sum $\left(I_{1}=S_{x}+S_{y}+S_{z}\right)$. The state of stress can now be plotted in dimensionless units (fractions or percent) on triangular-coordinate graph paper (for example, Dietzgen No. $340-\mathrm{TC}^{1}$; see also fig. $4 A$ ). Each of the normalized com-

${ }^{1}$ Any use of trade names is for descriptive purposes only and does not constitute endorsement by the U.S. Geological Survey.

FIGURE 4 (facing page).-Construction and properties of the triangular stress diagram. $A$, Procedure for plotting the point $O$ in the triangular diagram representing the state of stress $S_{y}>S_{x}>S_{z}$ in dimensionless units (fractions or in percent). $B$, Distribution of six points in different positions in the triangular diagram obtained by permutating the three stress components magnitudes along equivalent directions in an isotropic material. Loci of points where two stress components are equal in magnitude are the lines $A a, B b$, and $C c$. The point of intersection of these three lines defines the state of hydrostatic stress $(H)$. $C$, Structural definition of the six panels of the triangular diagram in terms of the preferred mode and orientation of faulting. The seismological focal-mechanism symbols in each panel indicate the preferred motion on preexisting faults; the $P$-axis (greatest compression direction) bisects the unshaded quadrant. $D$, Definition of states of stress that differ by a hydrostatic pressure. Point $O$ defines the state of total stress $(P=O)$ and point $O^{\prime}$ defines the state of effective stress $\left(P=P_{0}\right)$. The separation between points $O$ and $O^{\prime}$ is proportional to the added hydrostatic pressure $\left(P_{0}\right)$. $E$, Definition of the stress deviation associated with the state of total stress at $O$ in terms of a dimensionless parameter $\bar{r}$; that is, $\bar{r}=\left(J_{2}\right)^{1 / 2} / I_{1}$, where $I_{1}$ and $J_{2}$ are the first stress invariant and the second stress-deviation invariant, respectively. In an isotropic material $\bar{r}$ is the radius of a circle that contains all six equivalent stress states shown in figure $4 B$. Because an added hydrostatic pressure does not affect the stress deviation, points $O$ and $O^{\prime}$ in figure $4 D$ are equivalent in terms of $J_{2}$, but differ in position by the ratio $\bar{r}_{e} / \bar{r}=I_{1} /\left(I_{1}-3 P\right) . F$, Definition of the failure surfaces for frictional sliding on suitably oriented faults and fractures. The position of these surfaces in the triangular diagram vary only with the value of the coefficient of sliding friction $(\mu=0.6$ and 1.0$)$. 

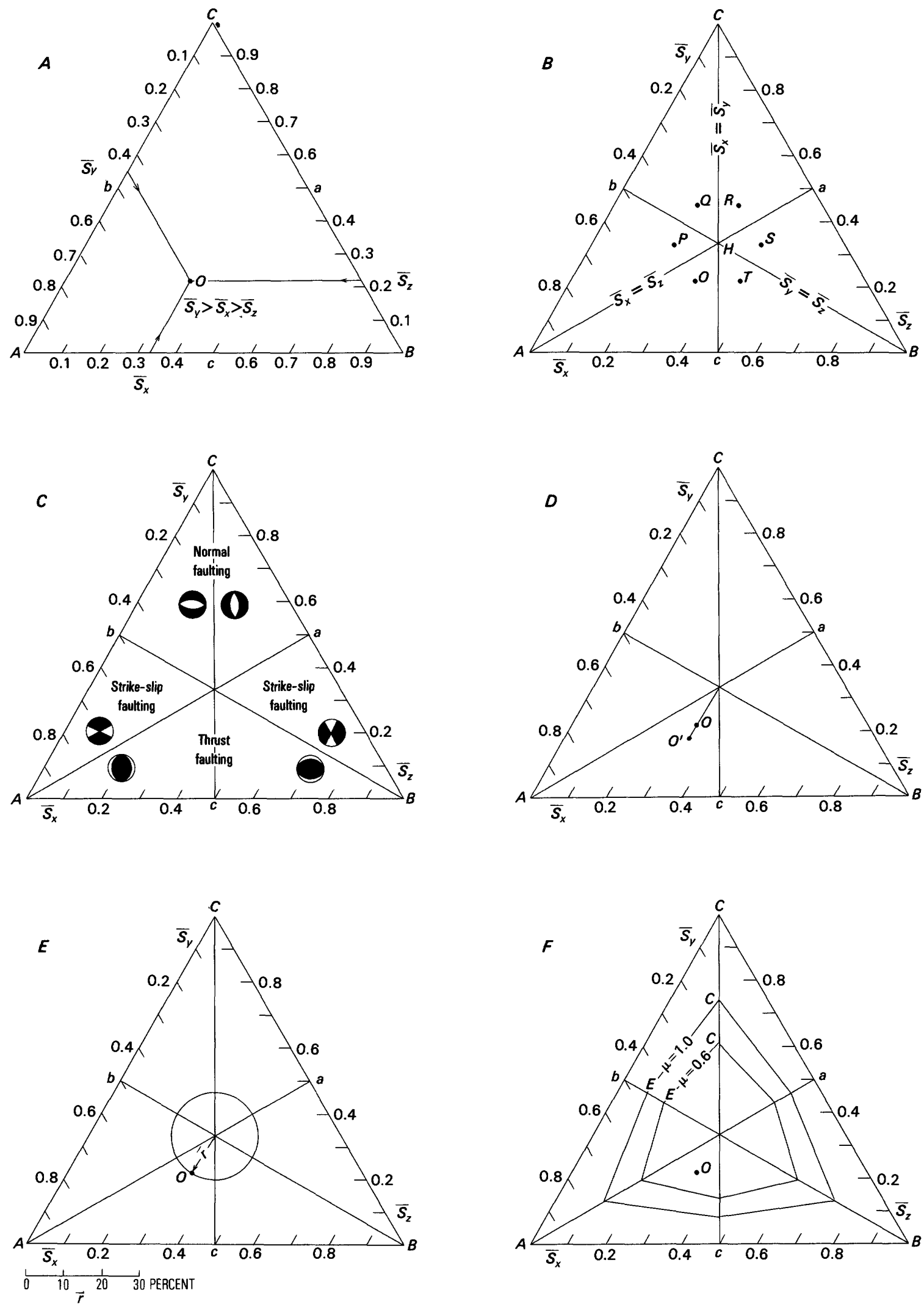
pressive stress components may vary from zero to one (100 percent), but all three combine in the triangular plane of projection at a single point, whose position varies with the relative magnitudes of the stress components.

Let $S_{x}, S_{y}$, and $S_{z}$ be the total normal stress components measured relative to a system of rectangular axes and transformed into the triangular diagram $A B C$ (fig. 4). If, for the present, the magnitudes of the stresses are such that $S_{y}>S_{x}>S_{z}$, then this triad of values can be represented in a triangular-coordinate graph (fig. $4 A$ ) as a single point, $O$, by (1) normalizing each stress component with respect to the first stress invariant, $I_{1}=S_{x}+S_{y}+S_{z}$, to obtain the ratios

$$
\bar{S}_{x}=S_{x} / I_{1}, \bar{S}_{y}=S_{y} / I_{1} \text {, and } \bar{S}_{z}=S_{z} / I_{1},
$$

(2) finding the values of each ratio, either as a fraction or in percent, along the appropriate sides of the diagram, $A B, C A$, and $B C$, respectively, and, finally, (3) projecting each value into the interior of the diagram as shown in figure $4 A$ to plot the point $O$ that now defines the stress condition $\tilde{S}_{y}>\tilde{S}_{x}>\tilde{S}_{z}$. The loci of points where two stress components are equal in magnitude are the lines $A a\left(\bar{S}_{x}=\bar{S}_{z}\right), B b\left(\bar{S}_{y}=\bar{S}_{z}\right)$, and $C c$ $\left(\tilde{S}_{x}=\tilde{S}_{y}\right)$. The intersection $(H)$ of these three lines defines the condition of hydrostatic stress, $\bar{S}_{x}=\bar{S}_{y}=\bar{S}_{z}$; it is the normal projection of the space diagonal in rectangular coordinates and, therefore, retains the same definition. Stress states for which one stress component is identically zero are plotted along the sides of the diagram: for example, along $A B$ for $\bar{S}_{z}=0$, along $C A$ for $\bar{S}_{x}=0$, and along $B C$ for $S_{y}=0$ (fig. $4 B$ ). Negative (tensile) stresses are plotted outside the diagram.

Five additional points, $P, Q, R, S$, and $T$ (fig. $4 B$ ), can be plotted at different positions in the diagram, provided the rock material is isotropic, by permutating the same relative magnitudes among the stress components. Thus, letting $\bar{S}_{y}>\bar{S}_{x}$, the magnitude assigned to $\bar{S}_{z}$ increases from smallest value at $O$, intermediate at $P$ to largest at $Q$. Similarly, but now letting $\bar{S}_{x}>\bar{S}_{y}$, points $R, S$, and $T$ are identified by decreasing magnitudes assigned to $\bar{S}_{z}$.

The triangular diagram (fig. $4 C$ ) is now divided into six panels in which the states of stress are distinguished by magnitude and orientation. Provided that $\bar{S}_{z}$ is vertical and $\bar{S}_{x}$ and $\bar{S}_{y}$ are horizontal, the panels can be identified with three types of faulting (Anderson, 1951). For example, the panels that include the points $O$ and $T$ are associated with thrust faulting, those that include $P$ and $S$ with strike-slip (wrench, transcurrent) faulting, and those that include $Q$ and $R$ with normal faulting. Likewise, motion on preexisting faults and fractures characterized by the orientation and inclination of the slip vector can be classified accordingly in the appropriate panels. The pairs of laterally adjacent, similarly named panels differ only by the orientation of the consequent or preexisting structures (faults and fractures).

The effective stresses defined by $\sigma=S-P$, where $P=P_{0}$ is the ambient interstitial pore pressure, can be plotted in the diagram (fig. $4 D$ ) using the relationship

$$
\sigma / I_{1}=\bar{\sigma}=\frac{S-P}{I_{1}-3 P}
$$

and following the plotting procedures as outlined earlier. The new point on the triangular diagram, for example $O^{\prime}$ representing the effective stress condition $\sigma_{y}>\sigma_{x}>\sigma_{z}$, is plotted outward from point $O$ on a line that passes through points $O$ and $H$. The separation between points $O$ and $O^{\prime}$ is proportional to the magnitude of the ambient pore pressure $P_{0}$. Thus, as the pore pressure is increased relative to $P_{0}$, the new effective stress states are plotted progressively farther outward from point $O^{\prime}$ along the same line that passes through $O^{\prime}, O$, and $H$. This important property of the triangular diagram is analogous to the translation of two-dimensional Mohr circles of constant radius (shear stress) along the normal stress axis in response to changing pore pressures.

Any point in the triangular diagram also defines a set of deviatoric stresses. It can be shown (Meldahl, 1944) that, in rectangular principal stress space, the deviatoric stresses are defined by a vector $r$ normal to the space diagonal whose magnitude is proportional to the second stress-deviation invariant, $J_{2}$ (equation 2). By transformation into the triangular diagram (fig. $4 E$ ) the normalized vector $\bar{r}$ originating at $H$ remains proportional to $J_{2}$ (equation 4 ); that is,

$$
\bar{r} I_{1}=\left(J_{2}\right)^{1 / 2}
$$

Consequently, point $O$ and, by permutation of the three normalized principal total stresses (fig. $4 B$ ), points $P$ through $T$ lie on a circle of radius vector $\bar{r}$; the circle being the projection of a cylindrical surface coaxial with $H$. The following caveat should be entered at this point: because fluid pressures do not affect the magnitude of the stress deviation, points such as $O^{\prime}$ (fig. $4 D$ ) that designate the effective stresses must have the same value of $J_{2}$ as point $O$. However, because of the way in which the triangular diagram is constructed, the radius vector $\left(\bar{r}_{\mathrm{e}}\right)$ terminating at point $O^{\prime}$ is greater than $\bar{r}$ by the factor $I_{1} /\left(I_{1}-3 P\right)$. This is the only exception to the general rule regarding the fractional length of the radius vector $\bar{r}$ and its relationship to the magnitude of $J_{2}$ (equation 7 ). 
Mechanical or structural stability can be assessed by the proximity of points on the triangular diagram to failure surfaces or envelopes. The simplest of these, the Coulomb criterion, can be used to approximate the limits of mechanical stability and is given, in terms of two effective principal stresses $\left(\sigma_{1}>\sigma_{3}\right)$, by the equation

$$
\sigma_{1}=2 C_{0}(q)^{1 / 2}+q \sigma 3
$$

where $C_{0}$ is the cohesive strength of intact rock (free of throughgoing fractures or faults), $q=\left(\left(\mu_{i}^{2}+1\right)^{1 / 2}+\mu_{i}\right)^{2}$, and $\mu_{i}$ is the coefficient of internal friction (Jaeger and Cook, 1968). For fractured or faulted rock with negligible cohesion $\left(C_{0} \rightarrow 0\right)$, equation 8 reduces to:

$$
\sigma_{1}=q \sigma_{3}=\left(\left(\mu^{2}+1\right)^{1 / 2}+\mu\right)^{2} \sigma_{3},
$$

where $\mu$ is the coefficient of sliding friction.

Figure $4 F$ shows a family of failure envelopes corresponding to values of the coefficient of sliding friction that range from 0.6 to 1.0 (valid for a wide variety of rocks (Byerlee, 1978)). Points $E\left(\sigma_{1}=\sigma_{2}\right)$ and $C$ $\left(\sigma_{3}=\sigma_{2}\right)$ can be found by using equation 9 , assigning an arbitrary value to either $\sigma_{1}$ or $\sigma_{3}$, and substituting the appropriate value for $\mu$. By rotating the principal effective stress components into different orientations, the envelopes close to form a polygonal set of curves whose positions in the triangular diagram vary only with the value assigned to $\mu$; these envelopes are the projections of polygonal cylinders coaxial with $H$. The straight-line segments connecting points $E$ and $C$ and so on around (finding their origin at the apices $(A, B$, and $C$ ) of the diagram) reflect the implicit assumption of the Coulomb criterion that the magnitude of the intermediate principal stress, $\sigma_{2}$, has no effect on the frictional strength of rock. Fracture-strength (rupture) envelopes can be plotted in a similar fashion using equation 8 , except that their positions in the diagram will vary with $C_{0}, \mu_{i}$, and stress.

This completes the introduction to the triangular stress diagram. In summation, a particular state of compressive stress can be represented as a single point in the diagram. Its position relative to the center of the diagram $(H)$ defines the operating stress deviation (that is, $\bar{r} I_{1}=\left(J_{2}\right)^{1 / 2}$, whereas its proximity to an appropriate failure surface determines the degree of mechanical stability in the dry state. The incorporation of pore pressure $\boldsymbol{P}$ shifts the point closer to the failure surfaces along a prescribed path. Clearly, a succession of complete stress determinations with depth in a certain locality can be represented by an equal number of points distributed within the diagram; the distribution of stress states thus represented perhaps being charac- teristic of the tectonic setting of the locality. Finally, the use of failure surfaces is not in the least restricted to the simplest ones alluded to earlier; more complex but informative ones may be constructed point by point provided a sufficient number of experiments involving different stress states have been made. These latter items will be elaborated in more detail in the following sections.

\section{FAILURE SURFACES}

The combinations of stresses at which rocks, on the one hand, fail either by fracture or frictional sliding or, on the other hand, by intracrystalline or cataclastic flow are best explored with careful experimentation in the laboratory (Jaeger, 1967, for review). The experimental results, often involving only two stresses in conventional triaxial compression $\left(\sigma_{1}>\sigma_{2}=\sigma_{3}\right)$ or extension $\left(\sigma_{1}=\sigma_{2}>\sigma_{3}\right)$ tests, are conveniently represented as failure envelopes in the two-dimensional Mohr circle diagram. The fact, however, that the envelopes for compression and extension tests on the same material rarely coincide (predicted otherwise by the Coulomb criterion) indicates the important and significant effect of the intermediate principal effective stress, $\sigma_{2}$, on rock behavior, particularly with respect to fracture propagation (Paterson, 1978, p. 39). Unfortunately, little is known about the fracture strengths of intact rock under truly triaxial stress states $\left(\sigma_{1}>\sigma_{2}>\sigma_{3}\right)$, and almost no knowledge exists about the frictional strengths of discontinuous rock under the same general stress conditions despite its obvious importance to practical rock mechanics.

The shear strengths of intact rock under true triaxial stress conditions have been investigated using specialized techniques and equipment (for example, Mogi, 1971). In triangular coordinates figure $5 A$ shows, as an example, the measured failure strengths of Mizuho trachyte (Mogi, 1971, fig. 7b) as a function of $\sigma_{2}$ at two constant values of $\sigma_{3}$. The corresponding Coulomb failure envelopes are shown in figure $5 A$ as thin straight lines for comparison purposes.

The two failure envelopes measured for the trachyte (fig. 5A) are only slightly convex outward, but are otherwise in fair agreement with the "straight-line" Coulomb envelopes. Taken together as contours, the measured failure envelopes define a portion of a failure surface that, with increasing stress levels, converges slowly toward the hydrostatic axis $(H)$. The generalized failure surface or its approximate equivalent (equation 8) for intact, isotropic rock material wraps around but remains symmetric about the hydrostatic axis (fig. $5 \mathrm{~A}$ shows only one of the six panels).

The failure strengths of anisotropic model materials 

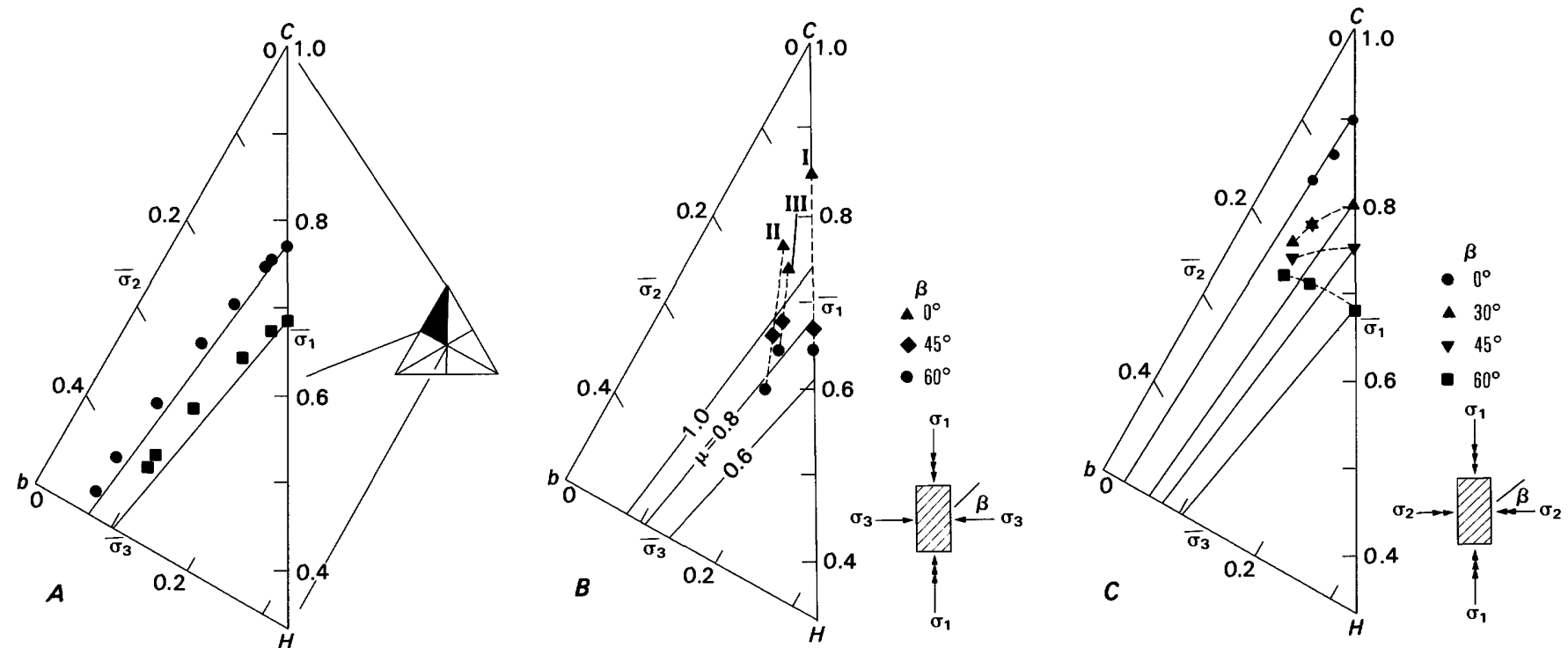

FiguRE 5.-Experimentally determined failure envelopes or surfaces. $A$. Panel of the triangular diagram showing the experimentally determined fracture strengths of Mizuho tracliyte as a function of $\sigma_{2}$ at constant $\sigma_{3}=45 \mathrm{MPa}$ (solid circle) and $\sigma_{3}=100 \mathrm{MPa}$ (solid square) (replotted from Mogi, 1971). Coulomb envelopes (thin straight lines, equation 8) are shown for comparison. B. Panel of the triangular diagram showing the variation in strength of a planar anisotropic rock nodel as a function of the angle $\beta$ (see inset) between the least-stress component $\left(\sigma_{3}\right)$ and the joint set. The intermediate stress conponent $\left(\sigma_{2}\right)$ is parallel to the joint set. The constant applied stresses are: data line I, $\sigma_{2}=\sigma_{3}=0.4 \mathrm{MPa}$; data line II, $\sigma_{2}=1.0 \mathrm{MPa}, \sigma_{3}=0.6 \mathrm{MPa}$; data line III, $\sigma_{2}=1.2 \mathrm{MPa}, \sigma_{3}=0.8 \mathrm{MPa}$. Lowest strength is achieved by frictional sliding at $\beta=60^{\circ}$ (data replotted from Reik and Zacas, 1978). Thin straight lines are the failure envelopes obtained by equation 9 (see also fig. $4 F$ ) for $\mu=0.6,0.8$, and 1.0. C. Panel of the triangular diagram showing the variation in strength of a planar anisotropic rock model as a function of the angle (see inset) between the intermediate stress component $\left(\sigma_{2}\right)$ and the joint set, and increasing magnitudes of $\sigma_{2}$. The least-stress component $\left(\sigma_{3}\right)$ is parallel to the joint set and constant at 0.4 $\mathrm{MPa}$. Dashed lines connect data points for the same angle $\beta$ for values of $\sigma_{2}$ equal to $0.4 \mathrm{MPa}, 0.8 \mathrm{MPa}$ and $1.2 \mathrm{MPa}$ (data replotted from Reik and Zacas, 1978). Thin straight lines are the Coulomb envelopes (equation 9) that imply no effect of the intermediate stress conponent $\left(\sigma_{2}\right)$ on strengtli; this condition is true only where $\beta=0^{\circ}$.

under general states of stress have been reported by Reik and Zacas (1978). Two examples will be considered here: in the first example the intermediate stress component $\left(\sigma_{2}\right)$ is parallel to the throughgoing set of discontinuities (fig. $5 B$ ), whereas in the second example the least-stress component $\left(\sigma_{3}\right)$ is parallel to the planar discontinuities in the testing material (fig. $5 C$ ). In the first sequence of tests ( $\sigma_{2}$ joint parallel), the usual reduction in strength is observed as the material anisotropy assumes angles $\left(\beta=60^{\circ}\right)$ for which sliding along preexisting joints is enhanced (fig. $5 B$ ). With reference to the sliding-friction envelopes obtained using equation 9 (see also fig. $4 F$ ), an approximate value of $\mu=0.8$ appears valid for the model material composed of lightweight concrete blocks (Reik and Zacas, 1978, table 1). The influence of the intermediate stress component is, at most, rather slight. The coefficient of sliding friction under general states of stress (data lines II and III, fig. $5 B$ ) is only slightly greater compared with that obtained in the conventional tests (data line I, fig. $5 B$ ), and perhaps is attributable to differences in surface roughness and misfit of the model blocks rather than to differences in the applied states of stress. Thus, sliding-friction coefficients determined by conventional compression testing of precut rock samples $\left(\sigma_{3}=\sigma_{2}=\right.$ confining pressure $)$ may be readily extrapolated to more general stress states provided no change in the stress field orientation with respect to the preexisting planes of weakness has occurred. Notice should be made that the present interpretation may change as more experimental results of the same general nature become available.

The interchange of the least and intermediate stress directions relative to the preexisting planes of weakness (fig. $5 C$ ) leads to entirely different results. This situation may result, for example, from the superposition of mining-induced stresses on the preexisting state of stress or, simply, by a reorientation of the stress field. The preliminary experiments by Reik and Zacas (1978, fig. 12) on a model material made up of hard plaster blocks show that, as expected under conventional triaxial stress conditions (line $H-C$, fig. $5 C$ ), the strengths decrease to a minimum value as the joint set assumes an angle of $30^{\circ}$ with respect to $\sigma_{1}$. However, increasing $\sigma_{2}$ by a factor of 3 above the constant $\sigma_{3}=0.4 \mathrm{MPa}$, increases the strength of the rock model by about 200 percent, even though the joint set is most favorably oriented to $\sigma_{1}$. In fact, no sliding occurs at $\beta=60^{\circ}$ at 
elevated magnitudes of $\sigma_{2}$; rather, a new shear fracture parallel to $\sigma_{2}$ is formed in compliance with the Mohr hypothesis. Clearly, in the $\sigma_{3}$ joint parallel example, the effect of the intermediate stress component is to diminish the material anisotropy to the point of "isotropy" $\left(\beta=0^{\circ}\right.$, fig. $\left.5 C\right)$ accompanied by a substantial increase in the shear strength; a condition not covered by the Coulomb criterion.

Although it may not be prudent to compare or even combine the information contained in figure $5 B$ and $5 C$ because of the two completely different model materials used in the tests (Reik and Zacas, 1978, table 1), just such an attempt will be made to illustrate a possible geologic situation (fig. 6). Suppose the effective principal stresses at failure are relabeled as follows: the greatest stress component is vertical $\left(\sigma_{v}\right)$ and the two remaining stresses are horizontal and are oriented either parallel to the joint set $\left(\sigma_{h t}\right)$ or at an obtuse angle to the same $\left(\sigma_{h o}\right)$; a stress state associated with normal faulting. The two failure conditions of a rock mass whose anisotropy (planes of weakness) is fixed in space at a small angle $\left(30^{\circ}\right)$ to $\sigma_{v}$, may then be combined synthetically into a short section of a single failure envelope (dashed line, fig. 6) whose overall shape is not known, but, for an anisotropic material, may no longer be symmetric about the hydrostatic axis $(H)$. Depending upon the magnitude of $\sigma_{h o}$, either frictional sliding ( $\mu=$ constant) along preexisting normal faults is the preferred mode of failure (left panel) or hardening takes place (right panel) that eventually leads to the formation of a new normal fault that cuts across the preexisting planes of weakness.

This brief exposition has been limited by lack of data to the brittle types of failure, friction and fracture, which are predominant in the shallow regions of the Earth's crust. At greater depths, as pressures and temperatures increase and depending upon the rock types involved, a transition to ductile types of failure modes will take place. This general change in behavior will manifest itself in the shapes of the failure envelopes or surfaces; they will become more rounded (to some extent shown in fig. $5 C$ ) until, in the purely plastic state, they assume a nearly circular shape.

\section{STRESS PATHS}

The portrayal of complete stress determinations as a function of depth in crustal rocks will be limited to a few examples. The data, replotted in the triangular stress diagram (or part of it), have been taken from the literature without modifications of any sort. As is customary, the measured stress components are labeled by their presumed orientations and, in part, by their relative magnitudes; also, they are assumed to be prin-

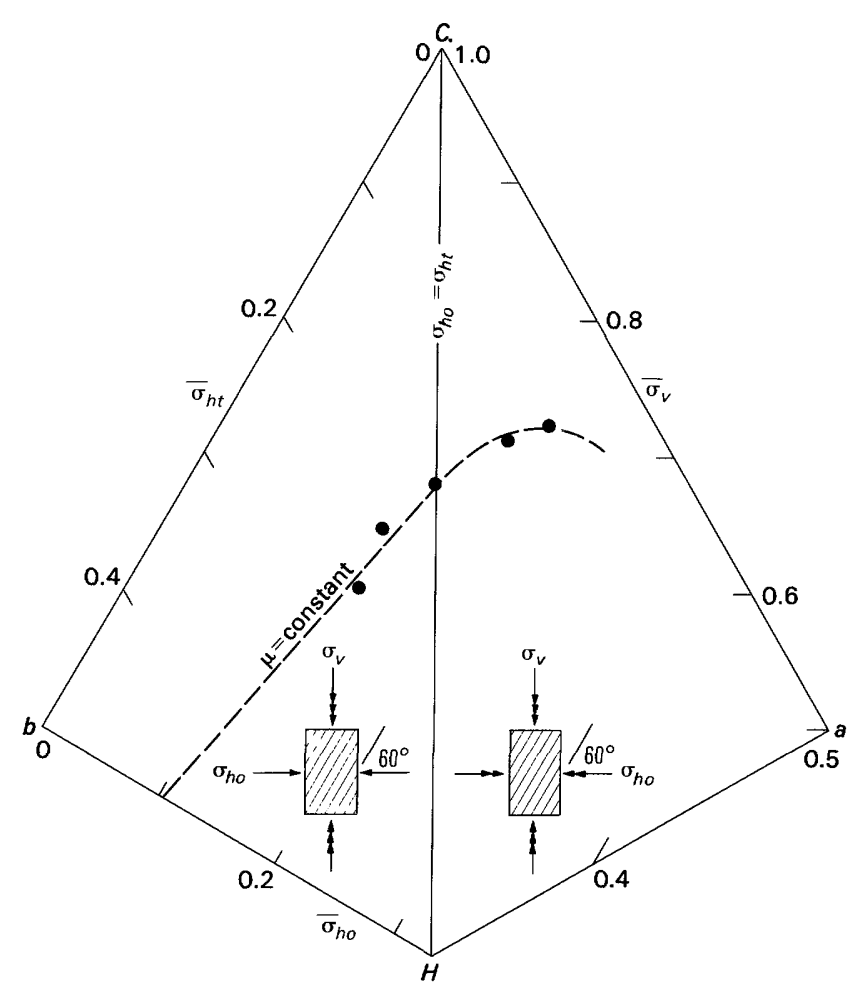

Figure 6.-Composite plot consisting of two adjacent panels of the triangular diagram that combines the test results for $\beta=60^{\circ}$ shown in figures $5 B$ and $5 C$. Coordinates of the plot are relabeled as $\sigma_{v}$-normalized vertical effective stress, $\sigma_{h t}$-normalized horizontal effective stress parallel to joint set, and $\sigma_{h o}$-normalized horizontal effective stress oriented at $60^{\circ}$ to the joint set. With increasing values of $\sigma_{h o}$ from $\sigma_{h o}<\sigma_{h t}$ to $\sigma_{h o}>\sigma_{h t}$, the failure mechanism of the joint set changes from frictional sliding (left panel) to the formation of a new fault that cuts across the preexisting joint set (right panel). Dashed line indicates the approximate position and shape (contour) of a failure envelope that, in the right panel, must bend as it approaches the Coulomb (isotropic) failure envelope $\left(\beta=0^{\circ}\right.$, see fig. $5 C$ ).

cipal stresses. Accordingly, the vertical and horizontal total stresses are defined as $S_{v} \neq S_{h \text { max }} \neq S_{h m i n}$. Because $S_{h m i n}$ is always smaller than $S_{h \max }$ in magnitude, only one-half of the triangular diagram will be used to display the data; in other words, the right-hand side of the complete diagram (fig. 4) is deleted, leaving the intervals along line $C c$ to measure $S_{v}$ (or $\sigma_{v}$ ). In the resulting half diagram, the three panels may be labeled with reference to the coordinate stress components by the letters $T, S$, and $N$ to indicate the three main types of faulting or slip along suitably oriented, preexisting structures (fractures and faults). In the case of slip, the appropriate seismological focal-mechanism symbols (see fig. 4C), if known, may also be used to identify the panels; in fact, by their abundance and distribution in certain localities, the choice of failure surfaces may be constrained. 


\section{TOTAL STRESS PATHS}

Figures 7 and $8 A$ present the field measurements of in situ total stress in sedimentary rocks (Bredehoeft and others, 1976) and in metasedimentary rocks (Gay, 1977), respectively. The range of depth in both sets of data differ considerably: $37-475 \mathrm{~m}$ in the shales and marlstones of the Piceance Creek basin in Colorado, and $110-2500 \mathrm{~m}$ in the predominantly quartzitic beds of the Witwatersrand Group in South Africa. The former were measured with the hydraulic-fracturing technique in vertical boreholes from the surface (table 1); the latter by overcoring in deep mines (Gay, 1977, table 1).

Both sets of data show considerable scatter in the measurements, but when summarized in each of the diagrams, some general features become apparent that are a direct consequence of the rate at which each total stress component increases with depth. Depth is taken to be colinear with the hydrostatic axis $(H)$; the data are thus projected on the diagram such that the shallow measurements appear near the bottom of the diagram and migrate upward with increasing depth. For example, in the sequence of measurements in sedimentary rocks (solid symbols, fig. 7), the shallow ones appear in the $T$ panel and progressively deeper ones traverse through the $S$ panel into the $N$ panel. The overall trend, whose projection in the diagram is the dashed line in figure 7, incorporates the majority of total stress states. This trend is called the "total stress" path.

The South African data (Gay, 1977), summarized in figure $8 A$, show a somewhat different distribution. As before, the measured stress states traverse the three panels with increasing depth following a generalized total stress path (dashed line, fig. $8 A$ ). The reflection of the total stress path at $R$ merely indicates that an overall azimuthal rotation of the horizontal stress components is taking place with increasing depth (see also Gay, 1977). More important is the observation that the deviatoric stress values (proportional to $\bar{r}$ see fig. $4 E$ and equation 7) diminish at first with depth to a minimum at $R$ (about $500 \mathrm{~m}$ ) and then increase once again (fig. $8 B$ ). The implication is that the mechanical stability of this rock system is greatest at those depths where the deviatoric stresses are smallest and virtually vanish near the hydrostatic axis $(H)$. In this respect, note that the frequency of mining-induced earthquakes (tremors) did not reach a near-steady level of 300 tremors per year since 1915 until the mining operations exceeded a depth of about $500 \mathrm{~m}$ (Gane and others, 1946).

Several studies have indicated that the otherwise tectonically stable region in southern Africa has been locally disturbed to a significant degree by the gold-mining process (Cook and others, 1966; McGarr and others,

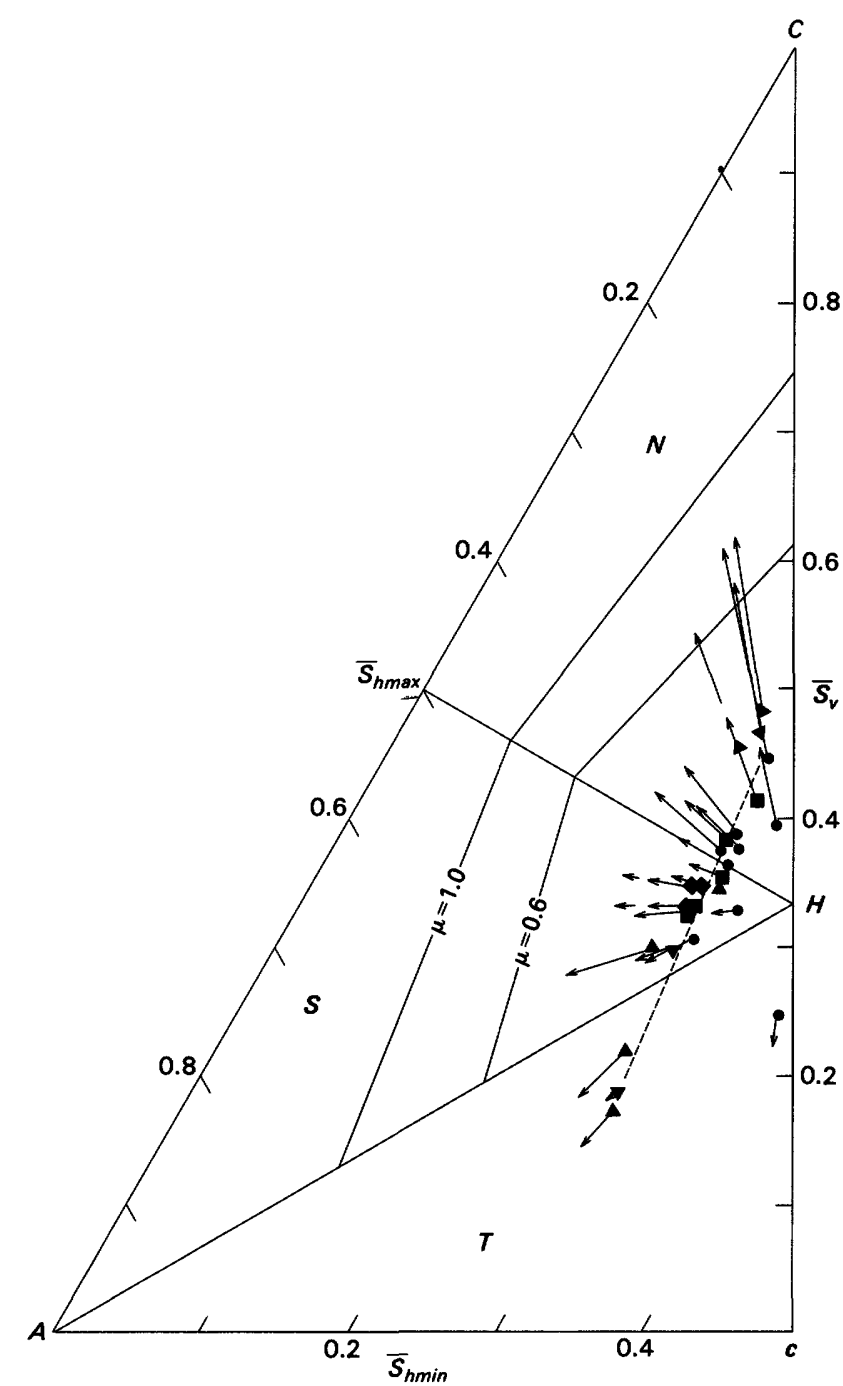

FIgURE 7.-Plot of the distribution of the total stress states (solid symbols) and effective stress states (arrowheads) measured in shales and marlstones, Piceance Creek basin, Colorado (modified from Bredehoeft and others, 1976). Shallow measurements are projected in the $T$ panel (bottom of the half diagram) and progressively deeper ones traverse through the $S$ and $N$ panels along a total stress path (dashed line). Surfaces connoting frictional sliding along suitable oriented faults are included in the $S$ and $N$ panels to approximate the upper limits to the effective stress distribution.

1979). The induced stress magnitudes at the head of longwall mines are estimated to be of the order of 100 MPa (vertical), which, when superimposed on the in situ total stresses at depth, are sufficient and of such orientation to generate new extensional fractures (cracks coalescing into rupture zones oriented at small angles to the greatest, vertical stress component (McGarr and others, 1979, fig. 4)) rather than slip on preexisting fractures and faults. Because the mines are apparently free of ground water, the combined stresses (total plus induced) are effective stresses, and failure 


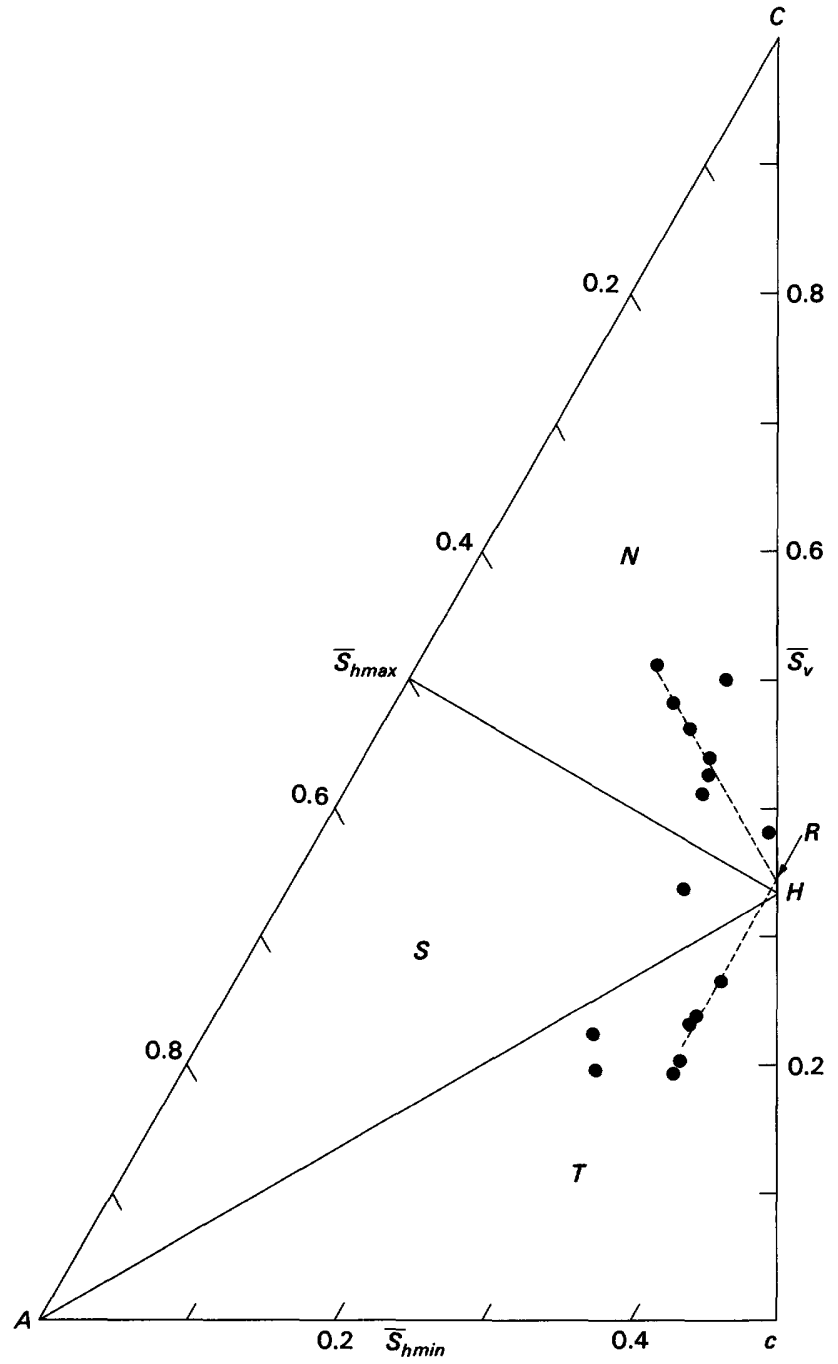

A

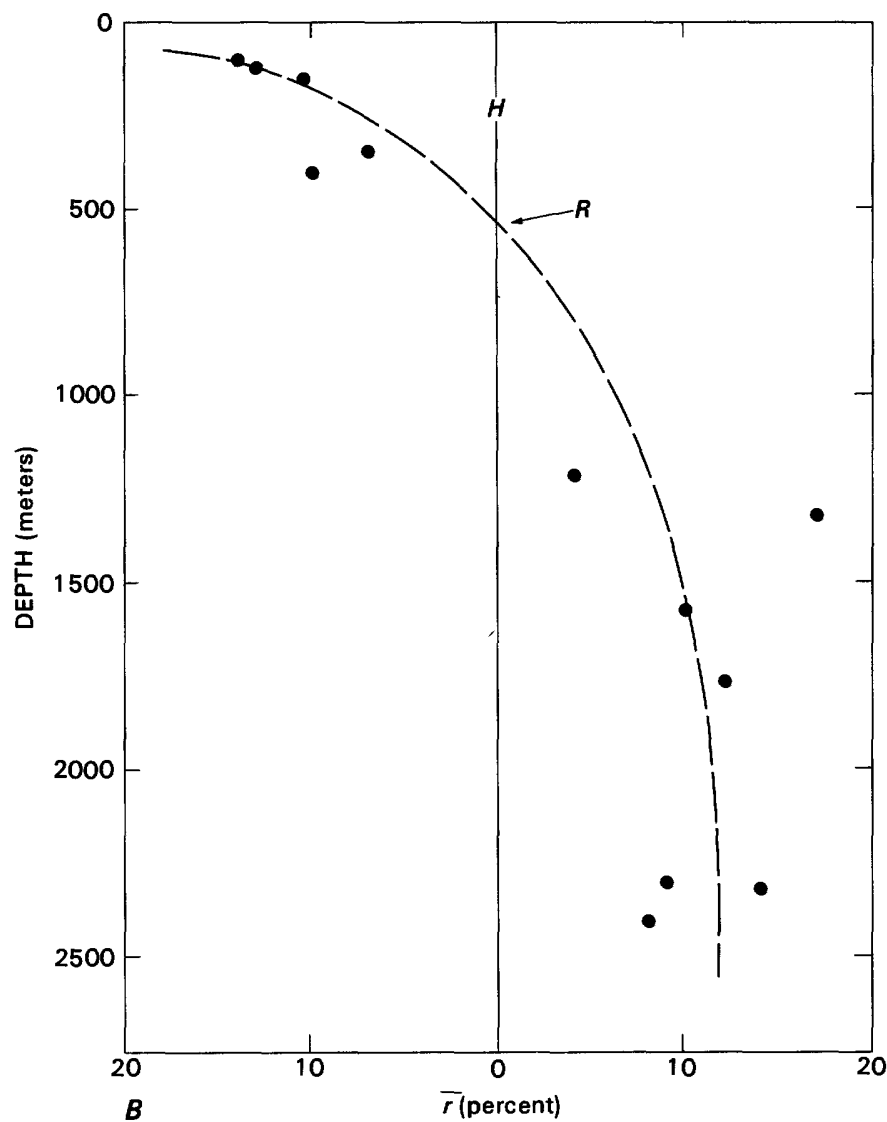

FIGURE 8.-A, Plot of the distribution of total stress states (solid symbols) measured in the quartzitic beds of the Witwatersrand Group, South Africa (modified from Gay, 1977). Reflection of the total stress path (dashed line) at $R$ indicates the azimuthal rotation of the horizontal stress components with increasing depth. $B$, Vertical section along the total stress path of figure $8 A$ showing the depth distribution of total stress states as a function of the dimensionless parameter $\bar{r}$ (equation 7 ). The magnitude of the deviation stress, $\sqrt{J_{2}}$, at first decreases with depth from about $5 \mathrm{MPa}$ at shallow depth to near zero $(500 \mathrm{~m})$ and then increases to about $20 \mathrm{MPa}$ at $2.5 \mathrm{~km}$ depth.

of intact rock predominates with perhaps one horizontal stress component approaching tension. An appropriate failure surface would lie almost at the left border of the diagram (not shown in fig. $8 A$ ). The mode of failure in these deep mines probably is similar to that observed in the model experiments (fig. $5 \mathrm{C}$ ) by Reik and Zacas (1978).

Although the presently available data base is too sparse to justify any firm conclusions, the apparent differences in the total stress paths trends shown in figures 7 and $8 A$ may reflect differences in the tectonic environments; that is, sedimentary basins versus crys- talline basement complexes. For instance, the four measured total-stress states in the Michigan basin (table 1) despite the scatter aline themselves in a manner similar to that shown in figure 7. The partial sets of stress measurements in the crystalline (granites and gneiss) rock masses in California, South Carolina, and Wisconsin (table 1), however, tend to group themselves in different positions in the diagram, but, on the average, follow trends (total stress paths) more like that shown by the South African data (fig. $8 A$ ). The data from these three different localities, all obtained in about the same depth interval $(100-300 \mathrm{~m})$ below the 
surface, also may be partitioned according to the geologic age of the host rocks; that is, the data from the Precambrian rocks (South Carolina and Wisconsin) are contained within the $T$ panel and those from the Jurassic rocks (California) fall in the $S$ panel. Considerably more work and data are needed before these matters and their importance or lack thereof can be considered seriously.

\section{EFFECTIVE STRESS PATHS}

Knowledge of the interstitial fluid-pressure distribution in the Piceance Creek basin sediments (Bredehoeft and others, 1976, table I) enables the calculation (equation 6 ) and plotting of the effective stresses with depth (arrowheads, fig. 7). Each point representing a measured state of total stress is shifted in the direction of the "effective stress" path (arrow), a distance that is proportional to the ambient pore-pressure magnitude (see fig. $4 D$ ). All effective stress paths used extrapolate back through the hydrostatic axis $(H)$. The distribution of effective stress state so obtained is closer to the limits of the stability field.

In conjunction with the sliding-friction envelopes (fig. $4 F$ ), the mechanical stability of the faulted sedimentary sequence at depths greater than $400 \mathrm{~m}$ appears to be tenuous at best (panel $N$, fig. 7 ). This general condition is similar to that inferred in the coastal plains of Texas and South Carolina (Zoback and others, 1978). A significant external disturbance could enhance slow, but over the longterm, continuous movement along preexisting and suitably oriented normal faults in the region. Likewise, at shallower depths, long-term creep may be accelerated by mined excavations (Agapito and Page, 1976) that cause the threshold creep strength to be exceeded.

Because the normal faults in the Piceance Creek basin are known to cut the surface, the use of the sliding-friction envelopes is restricted to the $N$ and $S$ panels (fig. 7). At these depths, the stress field is favorably oriented to the existing faults (Bredehoeft and others, 1976, fig. 16). At shallow depths, however, some other failure surface not associated with frictional sliding must operate whose general shape and position, although not known, may in part be located close to the shallow stress distribution in the $T$ panel.

The probable connection between fluids injected under pressure through boreholes and the generation of earthquakes in the subsurface, as well as the accompanying mechanisms, have been amply demonstrated by the controlled field experiments near Rangely, Colo. (Raleigh and others, 1972, 1976). The essential parameters of the experiment are reproduced in figure 9. Data point $I$ in the $S$ panel represents the state of total stress

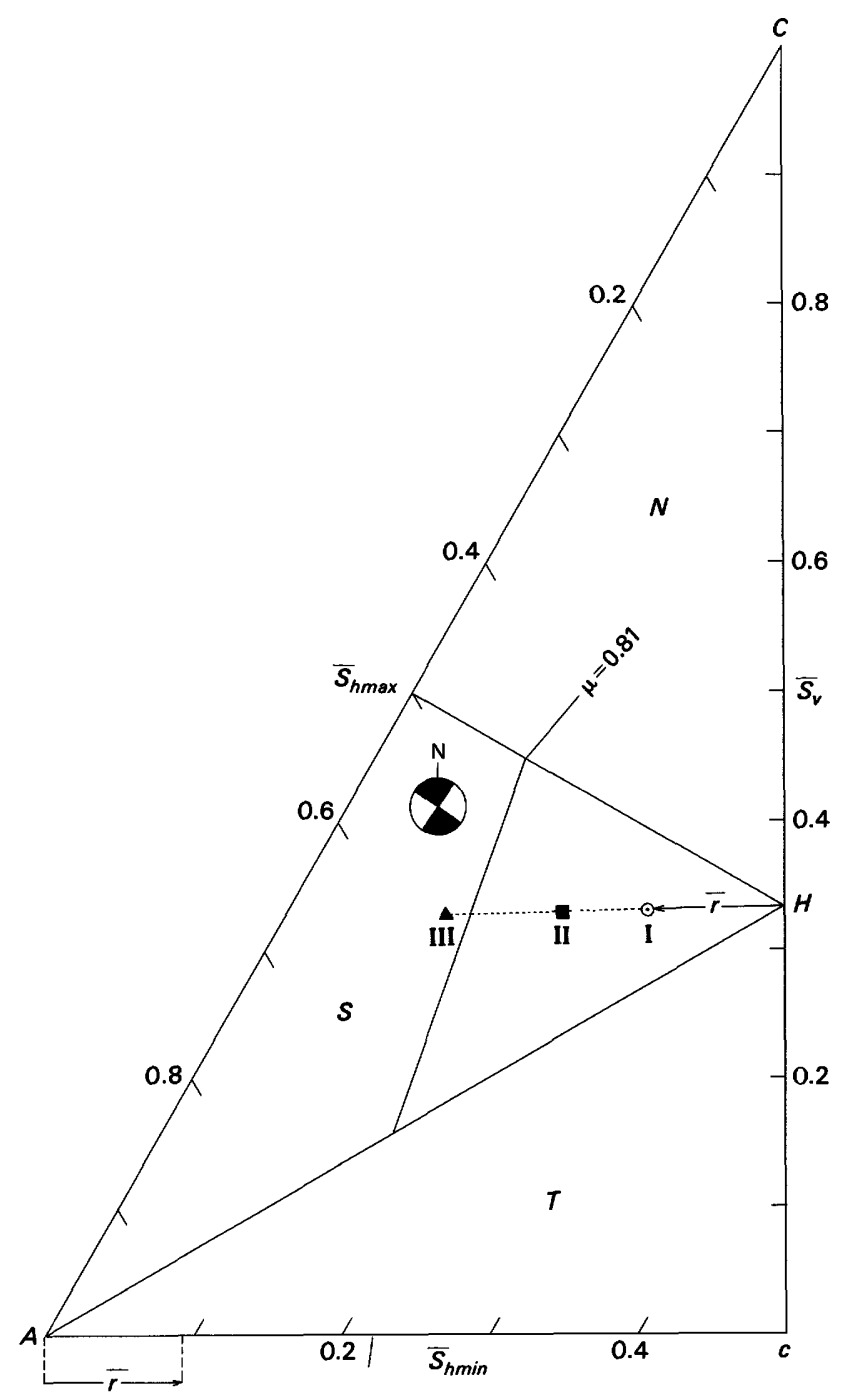

FIGURE 9.-Plot of the stress path associated with increasing hydrostatic pressure (dotted line). Data points I, II, and III identify the total, effective and critical stress states, respectively, determined by Raleigh and others (1972) in the Weber Sandstone, Rangely, Colo. Failure surface for $\mu=0.81$ is shown in the $S$ panel as a limit to the increasing hydrostatic pressure at which point a preexisting fault system fails and earthquakes with predominantly strike-slip motions are generated.

measured by Haimson (1973) at $1.86 \mathrm{~km}$ depth in the Weber Sandstone (table 2). Incorporating the measured value of the ambient pore pressure $\left(P_{0}=16.2 \mathrm{MPa}\right)$ in equation 6 gives data point II, the state of effective stress, which lies on an effective stress path that originates at point I and extrapolates back through $H$, the hydrostatic axis.

The existence of a subsurface high-angle fault system and the orientation of the operative stress field was inferred from the predominantly strike-slip focal mechanisms and the subsurface geology, and suggested that the failure mechanism was primarily frictional slid- 
TABLE 2.-In situ stress parameters, Rangely, Colo. [MPa, megapascals; leaders (--), not applicable]

\begin{tabular}{|c|c|c|c|c|c|c|c|}
\hline $\begin{array}{l}\text { Stress } \\
\text { orientation }\end{array}$ & $\begin{array}{c}\mathrm{S} \\
(\mathrm{MPa})\end{array}$ & $\begin{array}{c}\mathrm{I}_{1} \\
(\mathrm{MPa})\end{array}$ & $\begin{array}{c}\overline{\mathrm{S}} \\
\text { (percent) }\end{array}$ & $\begin{array}{l}\mathrm{P}_{0} \\
(\mathrm{MPa})\end{array}$ & $\begin{array}{c}\bar{\sigma} \\
\text { (percent) }\end{array}$ & $\begin{array}{l}\sqrt{J_{2}} \\
(M P a)\end{array}$ & $\begin{array}{c}\bar{r} \\
\text { (percent) }\end{array}$ \\
\hline None-..-.-.-.- & --- & 129.3 & --- & 16.2 & --- & 11.9 & 9.2 \\
\hline Vertical-....- & 42.7 & --- & 33.0 & --- & 32.9 & --- & --- \\
\hline $\begin{array}{l}\text { Horizontal } \\
\text { maximum----- }\end{array}$ & 55.2 & --- & 42.7 & --- & 48.3 & --- & --- \\
\hline $\begin{array}{l}\text { Horizontal } \\
\quad \text { min imum--...- }\end{array}$ & 31.4 & $\cdots$ & 24.3 & --- & 18.8 & --- & --- \\
\hline
\end{tabular}

ing (Raleigh, 1972). The coefficient of sliding friction of the sandstone was measured as $\mu=0.81$ (Byerlee, 1975). By use of this value in equation 9 , the appropriate failure envelope can be drawn in the diagram as shown in figure 9.

Increasing the fluid pressure in the sandstone reservoir by forceful injection from the surface led to the discovery of a critical pressure $\left(P_{c}=25.7 \mathrm{MPa}\right)$ above which a series of swarmlike earthquakes were triggered (Raleigh and others, 1972). By substituting this value of $P_{c}$ in equation 6 , data point III can be plotted on the extension of the effective stress path that connects point I and II, but slightly beyond the failure envelope. The discrepancy between point III and the intersection of the effective stress path with the straight friction envelope $(\mu=0.81)$ is small. As mentioned earlier, anywhere along this effective stress path the shear stresses remain unchanged and equal to the value at point I; that is, $\bar{r} I_{1}=\left(J_{2}\right)^{1 / 2}$ (table 2 ).

The general problem of earthquake triggering, either by fluid injection, filling of surface reservoirs, or even earth tides, has been treated rather exhaustively in the literature (Gupta and Rastogi, 1976; Klein, 1976). Provided that fluid pressures are transmitted unencumbered from the surface into initially highly stressed rocks at depth, a rather tight juxtaposition of several geologic factors is required to enhance the likelihood of induced earthquakes: (1) the presence of near-vertical faults or fractures, (2) an in situ stress state favorably oriented with respect to these structures, and (3) the intermediate stress component oriented in the plane of the fractures. The predominance of strike-slip motions, and to a lesser extent dip-slip (Gupta and Rastogi, 1976), associated with hydraulically induced earthquakes provides compelling evidence that $S_{v}$ (the intermediate stress component) exerts little or no influence on the frictional behavior of near-vertical fractures or faults. Evidently, all that is required to resolve this problem is a measure of the least and greatest effective stress components $\left(\sigma_{h \min }\right.$ and $\sigma_{\text {hmax }}$ ) at the hypocentral depths and an estimate of the frictional resistance (Byerlee, 1978) of the fractured mass. In these special cases (fig. 9), the triangular stress diagram merely re- produces the same mechanical information that can be obtained by different constructions (that is, the Mohr circle diagram, among others). However, the new diagram allows the reconciliation, although speculative depending on the quality and quantity of available data, of conflicting information obtained by different methods at the same location.

A case in point is the Lake Jacossee area in South Carolina. Shallow hydraulic-fracturing measurements between 120 and $250 \mathrm{~m}$ depth in metamorphic rock (gneiss) obtained by Haimson (1977b) resulted in the delineation of the states of stress and the orientation of $S_{\text {hmin }}:$ N. $30^{\circ}$ W. Composite focal-plane solutions (Talwani, 1977) of swarmlike earthquakes triggered by the filling of Lake Jacossee, on the other hand, indicated predominant strike-slip motions on near-vertical fractures or faults at a depth of about $1 \mathrm{~km}$ and dip-slip motions at greater depths to $3 \mathrm{~km}$. The average orientation of $S_{h \text { min }}$ (T-axis) at these depths is N. $35^{\circ} \mathrm{E}$.

Much of the available information is reproduced in figure 10 . The sequence of measured stress states plotted in the $T$ panel suggests a likely, but admittedly speculative, extrapolation of the stress distribution with depth by means of a total stress path (dashed line, fig. 10) that, after reflecting at $R$, continues into the $S$ panel. With increasing depths, the horizontal stress components assume new azimuthal directions. The consequent increase of the pore pressure at depth due to the filling of the surface reservoir may then shift the stress states closer to the failure surfaces along the effective stress path (dotted line, fig. 10) where the likelihood of slip along preexisting, near-vertical and northsouth-trending faults (see focal-mechanism symbol) is good. The preponderance of dip-slip events at greater depths $(3 \mathrm{~km})$ is indicated by the dashed arrow (fig. 10). At still greater depths, the effect of the intermediate stress component $\left(S_{\text {hmax }}\right)$ may become important and diminish the likelihood for further slip because of the increased shear strength (hardening) of the fractured rock mass.

This interpretation is in general agreement with the observed facts (Talwani and Stevenson, 1980). The apparent disagreement between the shallow and deep stress directions obtained by entirely different methods may be resolved by assuming that the rate of increase of the near-surface greatest stress component is smaller than that of the other two components so that at hypocentral depths it becomes the least-stress component. The two remaining stress components increase at about the same rate. The resulting state of stress at depth is also sufficiently high and of the proper orientation in a relatively small interval of depth to culminate in the generation of earthquakes following a rather small increase in the fluid pressure. Further occurrence of 


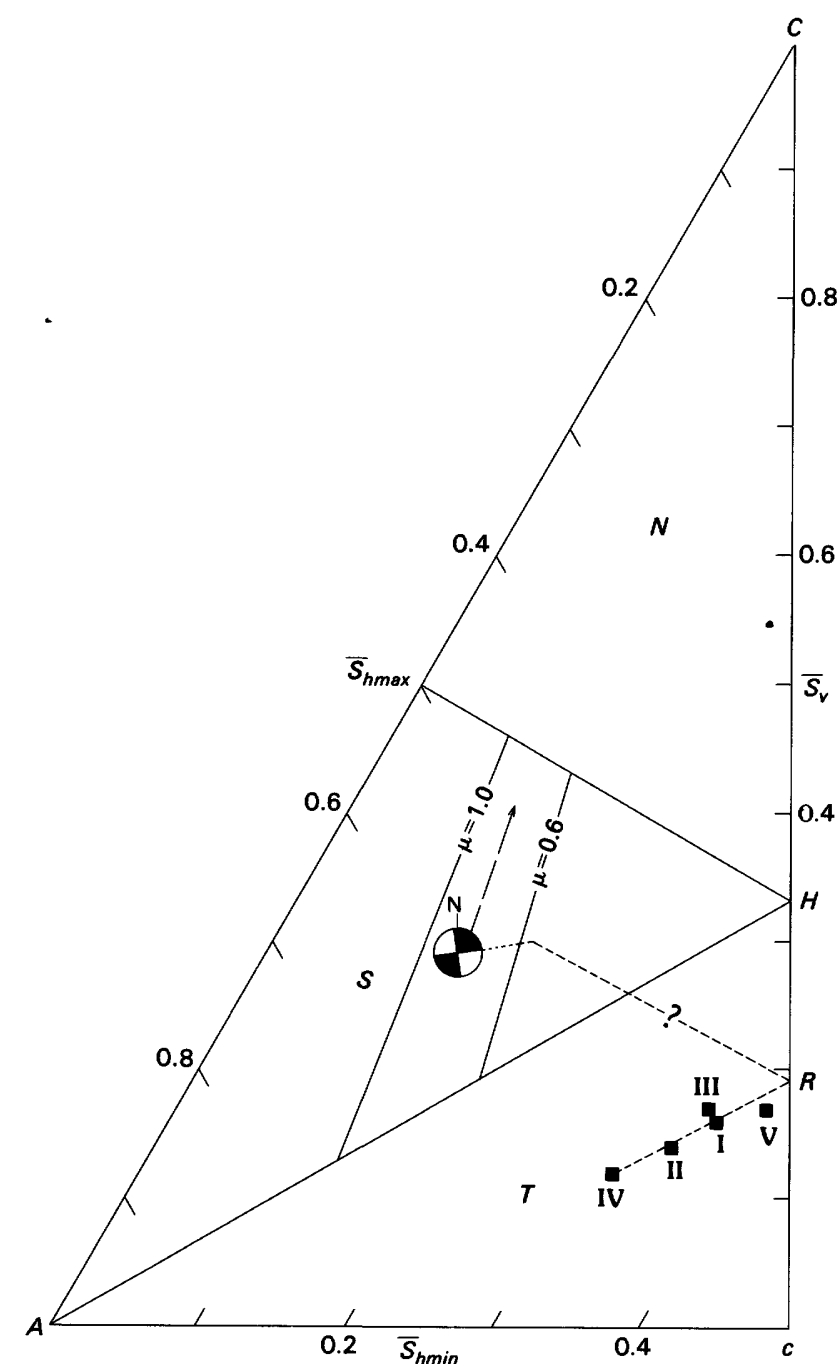

Figure 10.-Plot of the probable relation between stress states measured at shallow depths (solid symbols) by Haimson (1977b) and focal-mechanism solutions for strike-slip events at $1 \mathrm{~km}$ depth (Talwani, 1977; Talwani and Stevensen, 1980) near Lake Jacossee, S.C., by means of a total stress path (dashed line) and an effective stress path (dotted line). Dashed arrow indicates the approximate failure path leading to normal-faulting events at $3 \mathrm{~km}$ depth.

earthquakes at much greater depths $(>3 \mathrm{~km})$ may be prevented by the continued rotation of the stress field with respect to the "fixed" orientation of the prevailing structures.

One of the main differences between the two examples discussed in this section is the magnitude and rate of application of fluid pressures necessary to trigger the earthquakes. At Lake Jacossee, the earthquake sequence commenced about 7 months after the reservoir had reached its maximum head of $102 \mathrm{~m}$ (Talwani, 1977). The surface water-pressure of a hypothetical reservoir required to overcome the frictional resistance of the subsurface fault at Rangely could have been generated only by constructing a dam more than $900 \mathrm{~m}$ high. This improbable comparison, nevertheless, serves to show that the moderately stressed sandstone responded as it did (elastically) primarily because of the rapidity of the imposed disturbance; that is, high rates of injection through a borehole. Had the injection rate been much lower, as it would be in the hypothetical example of a manmade lake, then the threshold creep strength of the sandstone would have been exceeded only incrementally and, on the average, would have attenuated the protracted disturbance. The crystalline rocks under Lake Jacossee apparently are stressed near their shortterm strength and readily fail in response to small, but slow increases in fluid pressure.

\section{DISCUSSION AND CONCLUSIONS}

A new graphical method has been introduced that provides a clear and concise method of representing the measured stress states and their distribution in crustal rocks. Point measurements of compressive states of total stress in rocks, defined by the magnitudes and orientations of three mutually orthogonal stress components, are plotted in dimensionless units as points in a triangular plane of projection that is normal to the axis of hydrostatic stress (hydrostat or space diagonal in Cartesian coordinates). Each measured state of total stress occupies a unique position in the diagram and carries information on the relative depth, spatial ordering of the stress components in terms of relative magnitudes and orientations by their appearance in six different panels, and the magnitude of the stress deviation (stress difference, shear stress).

The dimensionless form of the triangular diagram provides for the convenient one-to-one comparison of the measured stress distributions in different structural-geologic environments (figs. 7 and $8 A$ ). Given sufficient data as a function of depth, the stress distribution may assume, with due allowance for scatter, an overall trend (total stress path) whose direction in the diagram may, in turn, be characteristic of the structural-geologic or tectonic environment. Furthermore, the very reason for the existence of these trends must reside in the fact that the conditions of equilibrium and continuity of stress in the rock column are satisfied. An additional point of interest is the observation, although uncertain at this time due to insufficient data, that the stress deviation as measured by the radius-vector $\bar{r}$ (fig. $4 E$ ) at first decreases with increasing depth to a minimum value and then increases again (figs. 7, 8A, and 10). The point (depth) of closest approach to the hydrostatic axis (center of the diagram) varies with each locality, 
but implies the attainment of maximum mechanical stability, particularly with regard to the strong, brittle rock types (fig. $8 A$ ).

Another advantage of the triangular diagram is that stress states that differ only by an added hydrostatic pore pressure are plotted as separate points (effective stresses) along an effective stress path that always rectilinearly extrapolates to the hydrostatic axis (figs. $4 F$ and 9). All these stress states, however, share the exact same stress deviation associated with the state of total stress (pore pressure, $P=0$ ) from which the path originates, even though with increasing hydrostatic pore pressure the points are plotted farther outward from the hydrostatic axis.

The stress distributions are limited in the extreme by some type of surface beyond which the stresses cannot increase without the rock material rupturing or yielding. Such surfaces can be constructed only point by point by conducting experiments or they can be determined approximately by invoking a suitable failure hypothesis or criterion. The latter approach appears iustified in characterizing the rupture strengths of isotropic rocks (fig. $5 A$ ) and the frictional strengths of properly oriented planar discontinuities (fig. $5 B$ ). The experimental approach evidently is required to determine fully the strength properties of anisotropic rock material under general states of stress; a problem of great practical importance to rock mechanics because no failure hypothesis of valid generality yet exists.

The main properties of the triangular diagram have been illustrated, to the extent possible, by using published measurements of total stress in crustal rocks (table 1). Most of these measurements have been obtained by the hydraulic-fracturing method that, in the least, provides reliable data on the magnitude of the stress component normal to the induced fracture; there is a correspondingly greater uncertainty in estimating the magnitude of the stress component parallel to the fracture. The vertical stress (only rarely measured) is calculated directly from the weight of the overburden. A further restriction stems from the working assumption that everywhere the principal stress components are vertical and horizontal. Thus direct comparisons with the results from other techniques (for example, overcoring) or, in terms of orientations, from earthquake focal-plane solutions are often only approximate. Nevertheless, the triangular diagram provides a practical means of combining these bits of information and, by so doing, perhaps improves and furthers the understanding of the behavior of crustal rocks.

Also, the examples used here have been restricted to the localities in which the measurements were obtained. Clearly, no longer can all data be combined from, say, all hard-rock localities (see figs. 1 and 2) because each data set plots in different positions or panels in the diagram and along different trends (compare figs. $8 A$ and 10). The situation is somewhat better in sedimentary environments that appear or are known to be tectonically quiescent.

The division of the triangular diagram into six panels (fig. $4 C$ ), or three panels in the half-diagram (figs. 7, $8 A, 9$, and 10), each connoting a precise arrangement of stress magnitudes and orientations, allows for the structural or tectonic analysis of the interaction and probable consequences of the prevailing stress field on the existing structures, if known. Strictly speaking, the analysis is a qualitative proposition, with the quantitative aspects improving as the data base increases.

\section{REFERENCES CITED}

Aamodt, R. L., 1977, Hydraulic fracture experiments in GT-1 and GT-2: New Mexico, Los Alamos Scientific Laboratory Technical Report LA-6712, 19 p.

Agapito, J. F. T., and Page, J. B., 1976, A case study of long-term stability in the Colony oil shale mine, Piceance Creek basin, Colorado, in Site characterization-Symposium on rock mechanics, 17th, Snowbird, Utah, 1976, Preprint-Proceedings: Utah Engineering Experiment Station, University of Utah, p. 3A4-1 to 3A4-6.

Anderson, E. M., 1951, The dynamics of faulting: London, Oliver and Boyd, $206 \mathrm{p}$.

Blair, A. G., Tester, J. W., and Mortensen, J. J., 1977, LASL hot dry rock geothermal project, July 1, 1975-June 30, 1976: New Mexico, Los Alamos Scientific Laboratory Technical Report LA6525-PR, p. 60-63.

Brechtel, C. E., Abou-Sayed, A. S., and Clifton, R. J., 1976, In situ stress determination in the Devonian shales (Ira McCoy 20402) within the Rome Basin: Terra Tek Report TR 76-36, 45 p.

Bredehoeft, J. D., Wolff, R. G., Keys, W. S., and Shuter, E., 1976, Hydraulic fracturing to determine the regional in situ stress field, Piceance Basin, Colorado: Geological Society of America Bulletin, v. 87 , no. 2 , p. $250-258$.

Brown, E. T., and Hoek, E., 1978, Trends in relationships between measured in situ stresses and depth: International Journal of Rock Mechanics and Mining Science, v. 15, p. 211-215.

Byerlee, J. D., 1975, The fracture strength and frictional strength of Weber sandstone: International Journal of Rock Mechanics and Mining Science, v. 12, no. 1, p. 1-4.

1978, Friction of rocks: Pure and Applied Geophysics, v. 116, p. $586-602$.

Cook, N.G.W., Hoek, E., Pretorius, J.P.G., Ortlepp, W. D., and Salamon, M.D.G., 1966, Rock mechanics applied to the study of rockbursts: South African Institute of Mining and Metallurgy Journal, v. 66 , p. 435-528.

Friedman, M., and Heard, H. C., 1974, Principal stress ratios in Cretaceous limestones from Texas Gulf coast: American Association of Petroleum Geologists Bulletin, v. 58, no. 1, p. 71-78.

Gane, P. G., Hales, A. L., and Oliver, H. A., 1946, A seismic investigation of the Witwatersrand earth tremors: Seismological Society of America Bulletin, v. 36, p. 49-80.

Gay, N. C., 1977, Principal horizontal stresses in southern Africa; Pure and Applied Geophysics, v. 115, no. 1-2, p. 3-10. 
Griggs, D. T., 1936, Deformation of rocks under high confining pressures-I, Experiments at room temperature: Journal of Geology, v. 44 , no. 5 , p. $541-577$.

Gupta, H. K., and Rastogi, B. K., 1976, Dams and earthquakes, in Developments in geotechnical engineering, v. 2: New York, Elsevier, $229 \mathrm{p}$.

Haimson, B. C., 1973, Earthquake related stresses at Rangely, Colorado, in New horizons in rock mechanics-Symposium on rock mechanics, 14th, Pennsylvania, 1972, Proceedings: American Society of Civil Engineers, p. 689-708.

1974, A simple method for estimating in situ stresses at great depths, in Field testing and instrumentation of rock: American Society for Testing and Materials Special Technical Publication 554 , p. $156-182$.

1976, The hydrofracturing stress measuring technique; method and recent field results in the U.S., in Investigation of stress in rock-Advances in stress measurement, International Society for Rock Mechanics Symposium, Sydney, Australia: Sydney, Australian Geomechanics Society, p. 23-30.

1977a, Crustal stress in the continental United States as derived from hydrofracturing tests, in The Earth's crust: American Geophysical Union Monograph 20, p. 576-592.

- $1977 \mathrm{~b}$, Design of underground powerhouses and the importance of preexcavation stress measurements, in Design methods in rock mechanics- Symposium on rock mechanics, 16th, Minneapolis, Minnesota, 1975, Proceedings: American Society of Civil Engineers, p. 197-204.

-1977c, Recent in situ stress measurements using the hydrofracturing technique, in Energy resources and excavation technology-Symposium on rock mechanics, 18th, Keystone, Colorado, 1977, Proceedings: Golden, Colorado School of Mines Press, p. $4 \mathrm{C} 2-1$ to $4 \mathrm{C} 2-6$.

-1977d, A stress measurement in West Virginia and the state of stress in the Southern Appalachians: EOS [American Geophysical Union Transactions], v. 58, no. 6, p. 493.

Haimson, B. C., Doe, T. W., Erbstoesser, S. R., and Fuh, G-F, 1976, Site characterization for tunnels housing energy storage magnets, in Site characterization-Symposium on rock mechanies, 17th, Snowbird, Utah, 1976, Preprint-Proceedings: Utah Engineering Experiment Station, University of Utah, p. 4B4-1 to 4B4-9.

Haimson, B. C., and Fairhurst, C., 1970, In-situ stress determination at great depth by means of hydraulic fracturing, chap. 28 , in Rock mechanics, theory and practice-Symposium on rock mechanics, 11th, Berkeley, California, 1969, Proceedings: Society of Mining Engineers, p. 559-584.

Haimson, B. C., Lacomb, J., Jones, A. H., and Green, S. J., 1974, Deep stress measurements in tuff at the Nevada test site, in Advances in rock mechanics: International Society of Rock Mechanics Congress, 3d, Proceedings, v. 2, pt. A, p. 557-562.

Haimson, B. C., and Stahl, E. J., 1969, Hydraulic fracturing and the extraction of minerals through wells, in Symposium on Salt, 3d, Cleveland, Ohio, Proceedings: Northern Ohio Geological Society, p. 421-432.

Handin, J., Hager, R. V., Friedman, M., and Feather, J. N., 1963, Experimental deformation of sedimentary rocks under confining pressure-Pore pressure tests: American Association of Petroleum Geologists Bulletin, v. 47, no. 5, p. 717-755.

Jaeger, J. C., 1967, Brittle fracture of rocks, chap. 1, in Failure and breakage of rock-Symposium on rock mechanics, 8th, Minneapolis, Minnesota, 1966, Proceedings: American Institute of Mining, Metallurgical, and Petroleum Engineers, p. 3-57.
Jaeger, J. C., and Cook, N. G. W., 1968, Fundamentals of rock mechanies: London, Methuen and Co., Ltd., p. 513.

Klein, F. W., 1976, Tidal triggering of reservoir-associated earthquakes: Engineering Geology, v. 10, no. 2-4, p. 197-210.

McGarr, A., and Gay, N. C., 1978, State of stress in the Earth's crust: Annual Review of Earth and Planetary Science, v. 6, p. 405-436.

McGarr, A., Spottiswoode, S. M., and Gay, N. C., 1979, Observations relevant to seismic driving stress, stress drop, and efficiency, in Fault mechanics: Journal of Geophysical Research, v. 84, no. B5, p. 2251-2261.

Meldahl, A., 1944, A new graphical method of representing strength characteristics: Brown Boveri Review, p. 260-267, August.

Mogi, Kiyoo, 1971, Fracture and flow of rocks under high triaxial compression: Journal of Geophysical Research, v. 76 , no. 5, p. $1255-1269$.

Paterson, M. S., 1978, Experimental rock deformation-The brittle field: New York, Springer-Verlag, $254 \mathrm{p}$.

Power, D. V., Schuster, C. L., Hay, R., and Twombly, J., 1975, Detection of hydraulic fracture orientation and dimensions in cased wells, in American Institute of Mining Engineers, 50th Annual Fall Meeting: Society of Petroleum Engineers, SPE 5626, p. 15.

Raleigh, C. B., 1972, Earthquakes and fluid injection, in Underground waste management and environmental implications: American Association of Petroleum Geologists Memoir 18, p. 273279.

Raleigh, C. B., Healy, J. H., and Bredehoeft, J. D., 1972, Faulting and crustal stress at Rangely, Colorado, in Flow and fracture of rocks: American Geophysical Union Geophysical Monograph 16 , p. $275-284$.

1976, An experiment in earthquake control at Rangely, Colorado: Science, v. 191, p. 1230-1237.

Reik, G., and Zacas, M., 1978, Strength and deformation characteristics of jointed media in true triaxial compression: International Journal of Rock Mechanics and Mining Science and Geomechanical Abstracts, v. 15, p. 295-303.

Renalli, G., and Chandler, T. E., 1975, The stress field in the upper crust as determined from in situ measurements: Geologische Rundschau, v. 64, p. 653-674.

Roegiers, J. C., and Fairhurst, C., 1973, The deep stress probe-A tool for stress determination [abs.], in New horizons in rock mechanics-Symposium on rock mechanics, 14th, Pennsylvania, 1972, Proceedings: American Society of Civil Engineers, p. 755.

Simonson, E. R., and Jones, A. H., 1976, Hydraulic fracture analysis of the Kinney No. 1 and No. 3 wells: Terra Tek Report TR $76-25,19 \mathrm{p}$.

Smith, M. B., Holman, G. B., Fast, C. R, and Covlin, R. J., 1976, The azimuth of deep, penetrating fractures in the Wattenburg field, in American Institute of Mining Engineers, 51st Annual Fall Conference: Society of Petroleum Engineers, SPE 6092, 12 p.

Swolfs, H. S., Lingle, R., and Thomas, J. M., 1977, Determination of the strain relaxations and their relation to subsurface stresses in Devonian shales: Terra Tek Report TR 77-12, $43 \mathrm{p}$.

Talwani,. Pradeep, 1977, Stress distribution near Lake Jacossee, South Carolina: Pure and Applied Geophysics, v. 115, no. 1-2 p. 275-281.

Talwani, P., and Stevensen, D., 1980, The August 25, 1979, Lake Jacossee earthquake and its implications on reservoir induced earthquakes: EOS [American Geophysical Union Transactions], v. 61, p. 293. 
Tyler, L. D., and Vollendorf, W. C., 1975, Physical observations and mapping of cracks resulting from hydraulic fracturing in situ stress measurements, in American Institute of Mining Engineers, 50th Annual Fall Meeting: Society of Petroleum Engineers, SPE 5542, $16 \mathrm{p}$.

Voight, Barry, 1966, Beziehung zwischen grossen horizontalen Spannungen im Gebirge und der Tektonik und der Abtragung, in International Society of Rock Mechanics Congress, 1st, Lisbon, 1966, Proceedings: Lisbon, Portugal, Laboratorio Nacional Engenharia Civil, v. 2, p. 51-56.

Wolff, R. G., Bredehoeft, J. D., Keys, W. S., and Shuter, E., 1974, Tectonic stress determinations, northern Piceance Creek Basin,
Colorado: Denver, Rocky Mountain Association of Geologists Field Conference, 1974, Guidebook 25, p. 193-197.

Zoback, M. D., and Healy, J. H., 1977, In-situ stress measurements near Charleston, South Carolina [abs.]: EOS [American Geophysical Union Transactions], v. 58, no. 6, p. 493.

Zoback, M. D., Healy, J. H., and Roller, J. C., 1977, Preliminary stress measurements in central California using the hydraulic fracturing technique: Pure and Applied Geophysics, v. 115, no. $1-2$, p. 135-152.

Zoback, M. D., Healy, J. H., Roller, J. C., Gohn, G. S., and Higgins, B. B., 1978, Normal faulting and in situ stress in the South Carolina coastal plain near Charleston: Geology, v. 6, no. 3, p. $147-152$. 
